IZA DP No. 4230

Lessons from Migration after EU Enlargement

Martin Kahanec

Anzelika Zaiceva

Klaus F. Zimmermann

June 2009 


\title{
Lessons from Migration after EU Enlargement
}

\author{
Martin Kahanec \\ IZA \\ Anzelika Zaiceva \\ IZA and University of Bologna \\ Klaus F. Zimmermann \\ IZA, DIW Berlin, Bonn University \\ and Free University of Berlin
}

Discussion Paper No. 4230

June 2009

IZA

P.O. Box 7240

53072 Bonn

Germany

Phone: +49-228-3894-0

Fax: +49-228-3894-180

E-mail: iza@iza.org

\begin{abstract}
Any opinions expressed here are those of the author(s) and not those of IZA. Research published in this series may include views on policy, but the institute itself takes no institutional policy positions.

The Institute for the Study of Labor (IZA) in Bonn is a local and virtual international research center and a place of communication between science, politics and business. IZA is an independent nonprofit organization supported by Deutsche Post Foundation. The center is associated with the University of Bonn and offers a stimulating research environment through its international network, workshops and conferences, data service, project support, research visits and doctoral program. IZA engages in (i) original and internationally competitive research in all fields of labor economics, (ii) development of policy concepts, and (iii) dissemination of research results and concepts to the interested public.
\end{abstract}

IZA Discussion Papers often represent preliminary work and are circulated to encourage discussion. Citation of such a paper should account for its provisional character. A revised version may be available directly from the author. 


\section{ABSTRACT}

\section{Lessons from Migration after EU Enlargement ${ }^{*}$}

The Eastern enlargement of the EU was an institutional impetus to the migration potential in Europe. While the overall numbers of migrants from the new member states in the EU15 increased between 2003 and 2007, this increase was distributed unevenly among countries. The proportion of these migrants in the EU15 remains smaller than that of non-EU27 migrants. The transitory arrangements may have diverted some migrants from the EU8 mainly to Ireland and the UK. Migrants from the EU2 continued to go predominantly to Italy and Spain. To date, there is no evidence that these primarily economic migrants would displace native workers or lower their wages (and even if crowding out happened in certain sectors or occupation, aggregate data suggest that such natives found well-paid jobs elsewhere), or that they would be more dependent on welfare than the natives. The drain of mainly young and skilled people could pose some additional demographic challenges on the source countries. However, the anticipated brain circulation may in fact help to solve their demographic and economic problems. While the ongoing economic crisis may change the momentum of several migration trajectories, free migration should in fact alleviate many consequences of the crisis and generally improve the allocative efficiency of EU labor markets.

JEL Classification: F22, J61

Keywords: migration, effects of migration, EU Eastern enlargement, free movement of workers

Corresponding author:

Klaus F. Zimmermann

IZA

P.O. Box 7240

D-53072 Bonn

Germany

E-mail: Zimmermann@iza.org

\footnotetext{
* This paper was prepared for the book "EU Labor Markets after Post-Enlargement Migration" edited by Martin Kahanec and Klaus F. Zimmermann. We are grateful to the participants of the IZA Workshop "EU Enlargements and the Labor Markets" for their helpful comments. We thank Margard Ody, Ross McRae, Holger Reinermann and Leila Young for research assistance.
} 
What once was unimaginable, then a vision, turned into reality, when eight Central and Eastern European countries ${ }^{1}$ (EU8), together with Cyprus and Malta, and Bulgaria and Romania (EU2), joined the European Union in May 2004 and January 2007, respectively. While cheered by many, EU enlargement brought about a number of concerns as well. The change it impinged on the European migration landscape was unprecedented in many aspects: the population size of the acceding countries was large; the differences in income between the old EU member states ${ }^{2}$ and the EU8 and the EU2 were substantial; essentially no migration between the former Soviet bloc and the West was allowed during the decades of separation by the "Iron Curtain"; and the new member states underwent a complex process of societal transformation to a free society and a market-based economy prior to their EU accession.

These specific circumstances partly explain the sensitivity of the migration issue among the general public as well as policy makers across Europe, who feared economic, social, cultural and political consequences of free east-west migration in an enlarged EU. Competition in the labor markets and for welfare benefits has prominently driven these fears. In contradiction of the European Union's fundamental principle of free movement, ${ }^{3}$ these fears have materialized as transitional periods of up to seven years, which restrict access of citizens from the EU8 and EU2 to the labor markets in the old member states. These transitional arrangements are based on the so-called " $2+3+2$ " formula: for the first two years following accession, access to the labor markets of the incumbent member states depends on their national laws and policies. National measures may be extended for a further period of three years; and could continue for a further two years, but only if there are serious disruptions in the respective receiving labor market.

Initially, only a few old member states opened their labor markets with no or mild transitional measures. Following the 2004 EU enlargement, Ireland, the UK and Sweden opened access to their labor markets immediately. ${ }^{4}$ Gradually, more

1 Including the Czech Republic, Estonia, Latvia, Lithuania, Hungary, Poland, Slovakia and Slovenia. We use EU10 whenever we refer to Cyprus and Malta as well.

2 The old member states (EU15) in the context of these enlargements include Austria, Belgium, Denmark, Finland, France, Germany, Greece, Ireland, Italy, Luxembourg, the Netherlands, Portugal, Spain, Sweden and the United Kingdom. EU25 denotes EU15 and EU10; EU27 includes EU2 as well.

3 Article 39 of the Treaty establishing the European Community entitles nationals of one EU member state to work in another EU member state under the same conditions as that member state's own citizens.

4 Immigrants from the EU8 who wish to work in the UK have to register with the Home Office administered Worker Registration Scheme if they are employed in the UK for a month or more. This requirement allows the authorities to monitor immigration and its impact on 
member states decided to lift restrictions, including Greece, Spain, Portugal and Finland (all May 1, 2006); Italy (July 27, 2006); the Netherlands (May 1, 2007); Luxembourg (November 1, 2007); France (July 1, 2008); and Belgium and Denmark (both May 1, 2009); whereas Germany and Austria have announced they will continue to impose restrictions on labor mobility until 2011, although Germany had passed legislation in late 2008 facilitating access for high-skilled migrants. ${ }^{5}$ As for the 2007 enlargement, ten EU25 member states (the Czech Republic, Estonia, Cyprus, Latvia, Lithuania, Poland, Slovenia, Slovakia, Finland and Sweden) liberalized the access of Bulgarian and Romanian workers to their labor markets during the first phase. ${ }^{6}$ The second phase for the EU2 countries started on January 1, 2009, and following the Commission's report, Spain, Greece, Hungary and Portugal have also opened their labor markets to the EU2 nationals. Denmark granted free access on May 1, 2009. Most of the remaining EU25 Member States have simplified their procedures or have reduced restrictions in some sectors or professions. ${ }^{7}$

Between 2003 and 2007, there was an increase in the number of immigrants from the new member states in the EU15. For EU8 migrants, the increase was particularly high in Ireland and the United Kingdom, while EU2 migrants continued to go to Spain and Italy. Such a concentration of migrant flows into some old member states may be an artifact of the variation in transitional arrangements, but also other important factors, such as geographic, linguistic or cultural distances between receiving and sending countries, as well as existing migrant networks. Indeed, the early evidence that we discuss in section 3 shows that there is no simple link between the scale of migration and the transitional arrangements. Overall, however, the proportion of non-EU27 nationals in the EU15 remains larger than that of migrants from the new member states.

the British labor market. Individual identification in the form of a Personal Public Service Number is required in order to gain employment or access to state benefits and public services in Ireland. Access to the welfare systems and entitlement to social benefits in Ireland and the UK depends on the duration of residence and employment. Sweden decided to apply European Community rules.

5 In April 2009, the German Federal Government notified the European Commission that Germany will prolong the mobility restrictions in place since 2004 . However, federal legislators only recently passed the "Arbeitsmigrationssteuerungsgesetz" (law on the regulation of labor migration, in effect since 1 January 2009), including rules for free mobility and labor market access of high qualified EU10 citizens and their family members. This legislation adds to an inconsistent German migration policy. Nonetheless, its potential strategic relevance should not be underestimated. http://www.bgblportal.de/BGBL/bgbl1f/bgbl108s2210.pdf.

6 In Finland, Cyprus and Slovenia, employment must subsequently be registered for monitoring purposes.

7 As of May 2009, see http://ec.europa.eu/social/main.jsp?catld=466\&langld=en 
The impact of these migration flows on the labor markets of destination and source countries depends primarily on their magnitude, composition, temporal nature, as well as the overall functioning of the countries' economies. The main objective of this paper is to broadly map what we know about the determinants and effects of the post-enlargement migration flows. Namely, we (i) discuss the theoretical underpinnings of migration causes and effects; (ii) describe the postenlargement migration flows; and (iii) investigate their impact on the receiving and sending countries including the impact on the European growth potential. Rather then discussing the potential repercussions of the ongoing economic and financial sector crisis on migration flows and their effects in Europe throughout the paper, we devote a special section to this topic. Finally, we identify the main scientific and policy challenges concerning migration in the enlarged EU.

\section{Theoretical Framework: Causes and Impacts of Migration}

Early theories of migration stress the significance of (expected) regional disparities in prosperity for migration decisions (Harris and Todaro, 1970). In general, migration theories imply the significance of international differentials, net of migration costs, in earnings and income levels; costs of living; unemployment rates; the quality of public goods; and the generosity of the welfare systems. Other factors, such as age or skills, affect individual potential to benefit from migration or ability to cope with the adjustment into the host society, as evident from the human capital theory (Becker, 1957; Sjaastad, 1962). The cultural, linguistic and geographical distances between pairs of source and destination countries directly affect not only the respective pecuniary, but also the psychological and social costs of migration or adjustment. Having a child or spouse, or broader social relationships, such as ethnic networks, may also play a significant role (Mincer, 1978; Massey, 1990). Migration can also serve as a risk-sharing strategy of a household as is emphasized by the new economics of migration theories that view households rather than individuals as decision-making units (Stark, 1991). Other factors mentioned in the literature include the earnings distribution (Borjas, 1985) and welfare regimes (Borjas, 1999; De Giorgi and Pellizzari, 2006) in the receiving and sending countries. Overall, migrants may be positively or negatively selfselected with respect to their observable and unobservable characteristics, both upon entry and exit (Borjas, 1987; Chiswick, 1999). Finally, the option of waiting and not migrating may have a positive value in the presence of uncertainty and irreversible costs of moving (Burda, 1995).

The impact of immigration on the destination labor market has been modeled by a number of studies, including Chiswick et al. (1992) and Chiswick (1980, 
1998). In these models, the effects of migration on receiving labor markets depend on the substitutability or complementarity of migrant and native labor. We illustrate these effects in a simple theoretical setting in Figure 1. Consider the impact of high-skilled immigration on an economy with labor markets for two types of native workers: high-skilled and low-skilled. ${ }^{8}$ The rise in the stock of high-skilled workers (see the shift in the supply curve from $\bar{S}^{0}$ to $\bar{S}^{1}$ in Figure 1a) moves the equilibrium point down from $\mathrm{C}^{0}$ to $\mathrm{C}^{1}$ at a lower wage $w_{h}^{1}$. Due to the complementarity of high- and low-skilled labor, the demand for low-skilled workers increases (see the shift of the demand curve in Figure 1b). Under a competitive market, wages rise from $w_{l}^{0}$ to $w_{l}^{1}$ at the full employment level $\bar{L}$. Under the regime with rigid union wage $\left(w_{U}\right)$ that is binding for the wages of low-skilled workers, as is the case in many European countries, the demand increase generates a higher level of employment of low-skilled workers instead ( $L_{\mathrm{U}}^{0}$ to $L_{\mathrm{U}}^{1}$ ). This increase in lowskilled employment feeds back into the market for high-skilled labor and causes an upward shift in the demand for high-skilled workers, counteracting the original wage decline from $w_{h}^{1}$ to $w_{h}^{2} \cdot{ }^{9}$

Figure $1 \mathrm{a}, 1 \mathrm{~b}$

Immigration in an economy with heterogeneous labor

(a) High-skilled

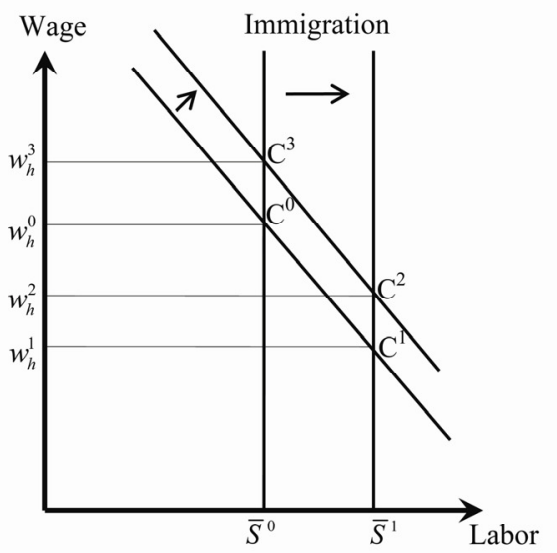

(b) Low-skilled

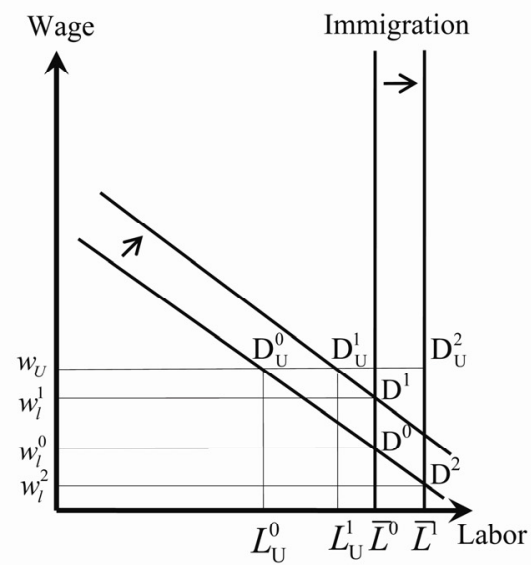

By a similar argument, low-skilled immigration decreases the wages to $w_{l}^{2}$ (under competitive markets) or increases unemployment from $\bar{L}^{0}-L_{\mathrm{U}}^{0}$ to $\bar{L}-L_{\mathrm{U}}^{0}$

8 Whether particular migrants can be regarded as skilled or unskilled relative to the natives also depends on the transferability of their skills acquired in the country of origin as well as their ability and willingness to adjust to the skill requirements of the host labor market. See the discussion in Kahanec and Zimmermann (2009).

9 The degree of complementarity determines whether the resulting wage is higher or lower than $w_{h}^{0}$. In the Figure, partial counteraction is shown. 
(under a rigid union wage) in the market for low-skilled labor. If the union wage is lowered in response to the increased unemployment, employment of low-skilled workers goes up. For example, if it is lowered to the pre-immigration competitive level $w_{l}^{0}$, employment will go from $L_{\mathrm{U}}^{0}$ to $\vec{L}^{0}$, leaving $\vec{L}-\bar{L}^{0}$ unemployed. This increases demand in the market for high-skilled labor due to the complementarity of high- and low-skilled workers in production, which increases wages of highskilled workers to $w_{h}^{3}$.

This simple analysis has a straightforward message: skilled immigration benefits unskilled and may hurt skilled native workers; and unskilled immigration hurts unskilled and may benefit skilled native labor. ${ }^{10}$ Broader positive effects of immigration may, however, overwhelm the potential negative effects that may concern some of the native workers. Highly mobile economic migrants typically improve the allocation of production factors, most notably human capital. The migrants often act as agents of knowledge transfer and international trade, and pools of skilled immigrants may attract high-tech investments (Bonin et al., 2008). In effect, immigration may expand a host country's production possibility frontier and thus increase the demand for native labor. On the other hand, some argue that immigrants may have unobserved characteristics that make them more likely to choose to live in countries with more generous welfare benefits and put pressure on their welfare systems. Furthermore, language problems, psychological trauma, employers' discriminatory practices, or legislative and institutional factors that inhibit adjustment and economic outcomes of immigrants may make them more dependent on welfare (Borjas, 1999; Brücker et al., 2002). If so, immigration could put pressure on the tax burden of native workers.

The effects in the source countries can be easily traced in the framework set up in Figure 1. It is straightforward to see that high-skilled emigration increases wages in the high-skilled market and via complementarities and the ensuing demand decrease reduces the wage (in a competitive market) or increases unemployment (under a union wage) in the low-skilled market. In the latter case, the decreased employment in the low-skilled market feeds back into the high-skilled market reducing demand and thus wages there. If it is the low-skilled who leave, wages in the low-skilled market increase (under a competitive market) or unemployment goes down (under a union wage). In the latter case, complementarities imply negative effects on wages in the high-skilled sector. Again, these direct effects may be mitigated or even reversed if indirect effects are taken into account. For example, if workers start returning to their home countries and circular migration emerges, the human capital they acquired while abroad would constitute brain gain for the source countries.

10 Kahanec and Zimmermann $(2008,2009)$ analyze the ensuing consequences for inequality in a theoretical and empirical framework. 


\section{Post-Enlargement Migration}

\section{a. Actual Migration Trends and Trajectories}

To provide an updated picture of post-enlargement migration from the new member states is a formidable task, as statistical data is continually being updated and is often missing. Several countries do not report migrants stocks or flows in their statistics. Migrants are often underrepresented in the official data. Moreover, the definition of a migrant differs across countries, making cross-country comparisons difficult. The distinction that is often ignored is between the foreign-born and foreign citizens, and between temporary and permanent migrants. Finally, illegal migration is not accounted for in the official data. In fact, much of the observed migration flows after enlargement may have been the legalization of people originating from the new member states who already lived in the old member states. Despite these difficulties, this section presents the statistics on the postenlargement migration trends in Europe making use of the latest and best available data and reviews evidence from selected recent studies. ${ }^{11}$

Looking first at the stocks of people from the new member states shows that the number of foreign residents from the EU8 in the old EU15 increased from almost 893,000 in 2003 to more than 1.91 million, or $0.5 \%$ of the population of the EU15 by the end of 2007 (Brücker and Damelang, 2009; Brücker et al., 2009). That suggests an average inflow (net immigration) of around 250,000 people from the EU8 per year since 2004, compared to 62,000 per year between 2000 and 2003. The proportion of foreign residents from Bulgaria and Romania have been continually increasing since 2000 , and in 2007 amounted to around 1.86 million people, or $0.5 \%$ of the EU15 population. Similarly, the European Commission suggests that the proportion of nationals from the new member states have increased, and in 2007 nationals from EU10 and EU2 amounted to 0.5 and $0.4-0.5 \%$ of the EU15 population, respectively (European Commission, 2008a, b). The corresponding figure for 2003 was $0.2 \%$ for each group. However, these reports also suggest that the overall increase in immigration after 2004 was rather limited when compared with the population sizes of both sending and receiving countries, and in the case of EU10 migrants was mainly attributable to the increases in Ireland, the United Kingdom and also Austria (European Commission, 2006a, b,

11 A separate strand of the literature investigated the migration potential, analyzing either migration intentions in the accession countries or using extrapolations or forecasts based on historical data for other countries. For the reviews of these studies see, for instance, Alvarez-Plata et al. (2003), Boeri and Brücker (2005), Zaiceva and Zimmermann (2008), Brücker et al., 2009. 
$2008 \mathrm{a}, \mathrm{b})$. For sake of comparison, nationals from other EU15 countries constituted $1.7 \%$ of the EU15 population in 2007 (1.6\% in 2003); while non-EU27 nationals amounted to $4.5 \%$ (3.7\% in 2003) (European Commission 2008a, b). Figures 2 and 3 document these trends for the available origins and destinations.

Although the statistics on stocks of residents usually rely on registers of foreign population, which tend to understate return migration, since no incentives to deregister exist, they provide several interesting observations. First, they show that the largest increase in the share of EU8 residents since the 2004 enlargement was in Ireland and the UK. Indeed, almost $70 \%$ of the immigrants from the EU8 have been absorbed by the UK and Ireland since 2003, and their share in the total number of foreign residents from the EU8 in the EU15 increased between 2002 and 2007; while the share of the traditional recipients, Austria and Germany, declined (Brücker et al., 2009; Brücker and Damelang, 2009; European Commission, $2008 \mathrm{a}, \mathrm{b})$. Thus, it is likely that a "migration diversion" has occurred into the countries that opened up their labor markets early (Brücker et al., 2009; Boeri and Brücker, 2005). Otherwise, network effects and geographical proximity would probably have attracted many more migrants to Austria and Germany.

However, other factors may also have contributed to the unexpectedly strong rise in the numbers of Eastern European immigrants in the English speaking EU15 countries: many immigrants have studied English at home and valued the opportunity to use, improve or study it in these countries (Anderson et al., 2006); enlargement may have contributed to the legalization of previously illegal immigrants already in the country, which would imply a pure statistical effect; and demand-driven immigration, especially in the case of Ireland, was likely to occur in any case to fill in the available vacancies.

Second, the picture is different for the EU2 countries because the main destination countries for these immigrants are Spain and Italy (Figures 2 and 3). The proportion of these immigrants has also increased during the 2000s facilitated by bilateral agreements between Spain and Italy and the sending countries and legalizations of immigrants there (Brücker et al., 2009). Moreover, given the relative geographic, and in the case of Romanians also linguistic proximity to Italy and Spain, these migration trends suggest that geographical and linguistic distance as well as networks are indeed very important pull-factors. In general, however, the importance of geographical distance as a migration deterring factor has declined over time with the increased availability of low-cost airlines (see Box 1, Pollard et al., 2008; Brücker and Damelang, 2009; Brücker et al., 2009). 
Figure 2

Share of foreign nationals from the new member states resident in the EU15

EU8

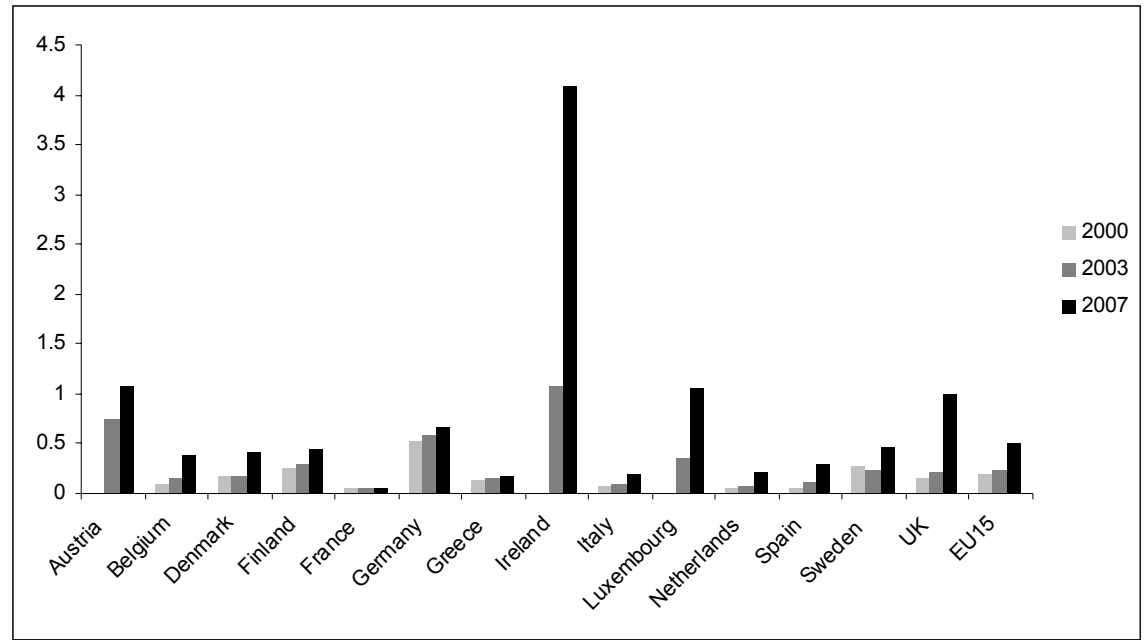

EU2

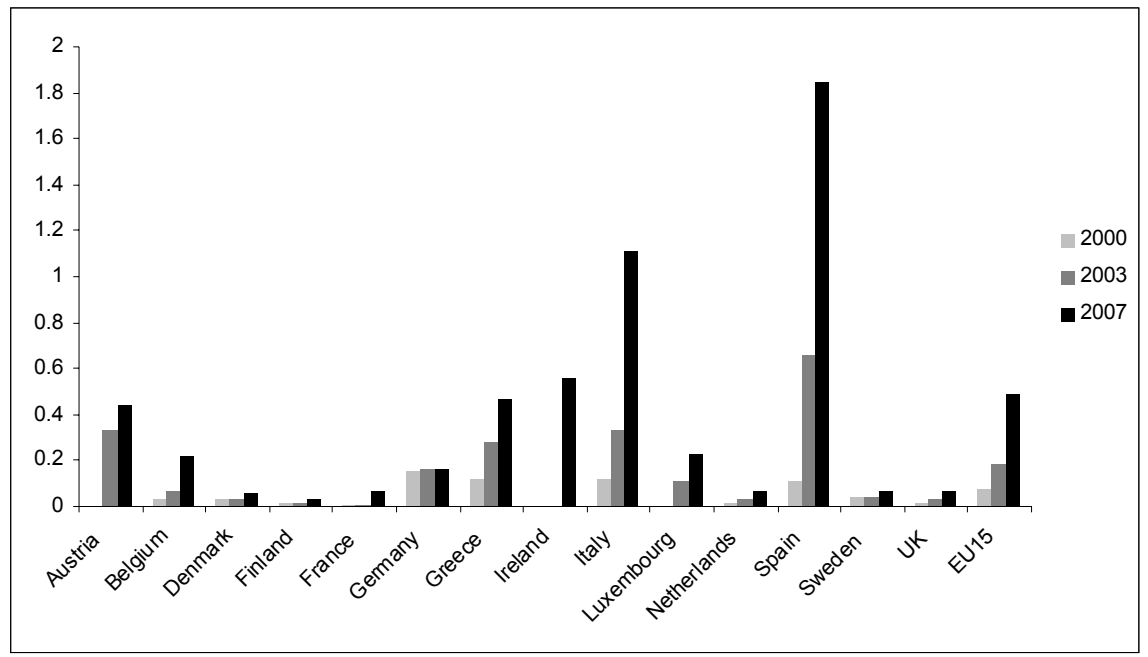

Source: Brücker and Damelang (2009), Tables 3b and 4b.

Notes: In \% of the host population. Data is from National Statistics, apart for France and Greece (LFS, annual), Ireland (Irish LFS, 4th quarter), Italy (2000: Eurostat), UK (UK LFS, 2nd quarter). In 2007, estimates are provided for EU8 residents in Luxembourg and Spain. Partially no data available: Austria (2000), Ireland (EU8: 2000, 2003 (2004 instead), EU2: 2000, 2003), Luxembourg (2000). No data at all for Portugal. 
Figure 3

Share of foreign nationals resident in the EU15

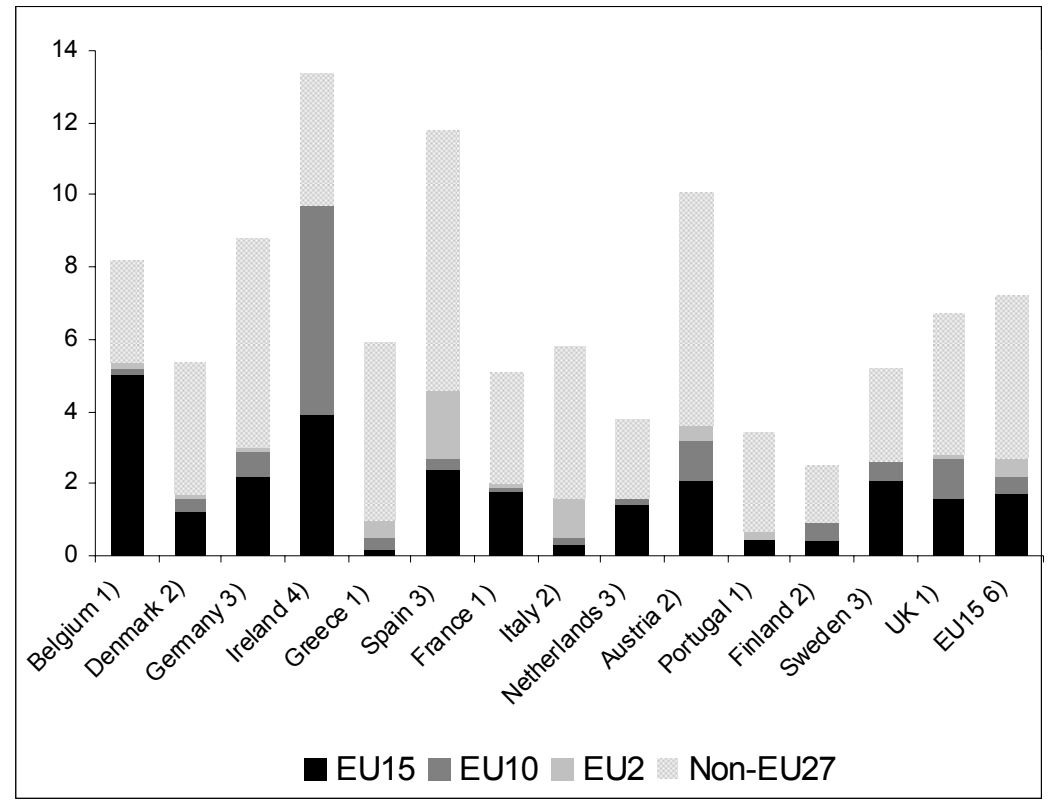

Source: European Commission (2008a), Table A1.

Notes: 2007. In \% of the total population. Luxembourg is excluded due to the scale comparability; proportion of EU15 nationals in Luxembourg is 37.3 , of EU10 nationals 0.8 , of non-EU 3.4 and is missing for EU2 nationals. Choice of data sources according to data availability for individual countries. For population statistics end of year data, for LFS 4th quarter data. Figures are not fully comparable between member states due to the use of different sources. Data from the LFS should be treated with some caution due to limitations of the survey with regard to foreign populations, in particular concerning coverage of very recent migrants and collective households, relative levels of non-response and small sample sizes. 1) EU LFS quarterly data, 4th quarter. 2) National and Eurostat Population Statistics. 3) Eurostat population statistics, 2007 DG Employment estimate. 4) CSO Ireland, Quarterly National Household Survey, 4th quarter; for 2003 3rd quarter 2004; Nationals from BG and RO included under non-EU27 nationals until 2006 and under EU10 nationals in 2007. 5) EU LFS quarterly data, 4th quarter. EU10 and EU2 nationals included under non-EU27. 6) EU totals and sub-totals are only of an indicative nature, as they are the sum of country values that stem from different sources; EU totals and sub-totals include country data which are not shown individually due to small sample sizes. Data for Ireland on EU2 migrants and for Portugal on EU10 migrants are not available. See also notes in European Commission (2008a).

Third, based on the available data, Figure 3 also indicates that while the overwhelming proportion of migrants from the EU10 is in Ireland, and the largest proportion of EU2 migrants is in Spain and Italy, non-EU27 migrants constitute the majority among all foreign nationals in all the old member states, except for Ireland (where it is EU10 migrants) and Luxembourg (not shown) as well as Belgium (where it is EU15 migrants). It is also worth noting that between 2003 and 2007 the number of foreign residents from the EU8 also significantly increased in countries outside the EU15, such as Iceland and Norway (Brücker and Damelang, 2009; Brücker et al. 2009). 
Turning now to the available data on actual migration flows, it is important to distinguish gross and net immigration. Since the Eurostat data on emigration are missing for most countries and years, we present trends only for gross immigration rates for the four selected EU15 countries for which the data was available: Sweden, the UK, Spain and Germany. Immigration rates are calculated as the proportion of total immigrant inflows to the receiving country's population. As can be seen from Figure 4, gross immigration rates of EU12 citizens have been steadily increasing in all four countries, including the period of EU enlargement. ${ }^{12}$

Figure 4

Gross immigration rates in selected EU15 countries
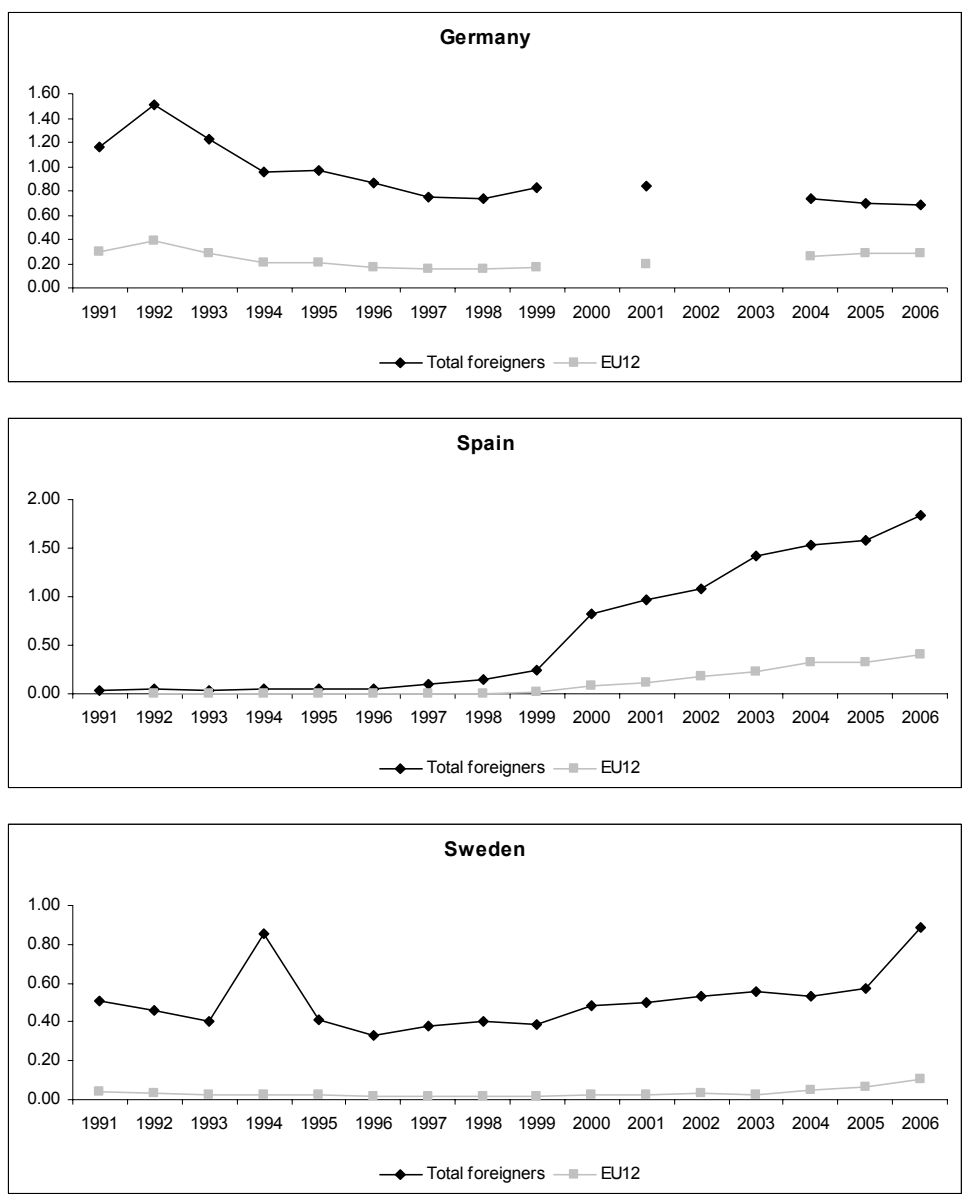

12 Note, however, that when calculating total immigration from the EU12, the figures were missing in several years and countries and in several cases zeros were reported. 
Figure 4 (continued)

Gross immigration rates in selected EU15 countries

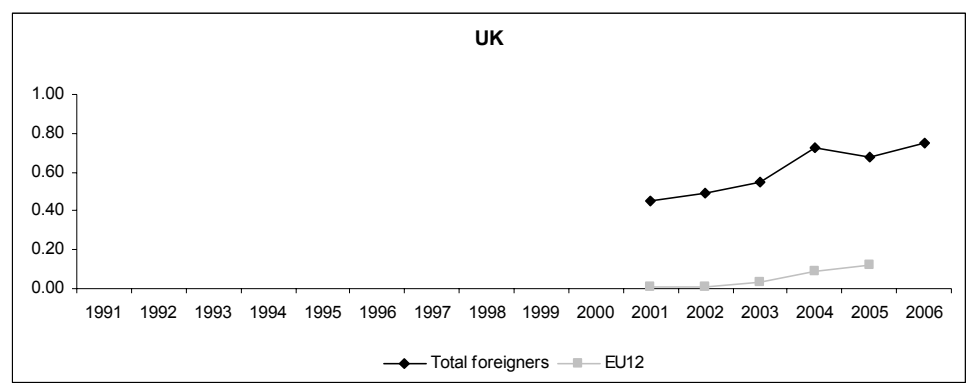

Source: Own calculations based on data from the Eurostat online database for Population and Social Conditions / International Migration and Asylum / International Migration Flows available at: http://epp.eurostat.ec.europa.eu/portal/page?_pageid=1090,30070682,1090_30298591\&_dad=portal\&_sc hema=PORTAL

Notes: Immigration rates are calculated in \% of the receiving country's population. For Germany, data for the Czech Republic, Slovenia and Slovakia are missing in 1991, for the Czech Republic, Cyprus, Malta and Slovakia in 1992, for Cyprus and Malta in 1993-1996. For Sweden, the data for the Czech Republic and Slovakia are missing in 1992. For Spain, the data for the Czech Republic, Slovenia and Slovakia are missing in 1992, for Slovenia in 1993, for Cyprus, Latvia, Malta and Slovakia in 1995, for Estonia, Latvia and Lithuania in 1996. Zeros are reported in Germany for Cyprus and Malta in 1998, 1999 and 2001, for Estonia, Latvia and Lithuania in 2001; in Sweden for the Czech Republic, Lithuania, Slovenia and Slovakia in 1991 , for Malta in 1994 and 1996; in the UK for the Czech Republic and Estonia in 2001 and 2002, for Malta in 2001, for Slovenia in 2001-2005, for Slovakia in 2002.

Figure 5 presents data on gross inflows to the UK and Ireland: the Worker Registration Scheme (WRS) applications and National Insurance Number (NINO) allocations in the UK and Personal Public Service Number (PPSN) allocations in Ireland. ${ }^{13}$ Overall, Figure 5 shows that the total number of nationals from the EU8 have been increasing since 2004, and they reached a maximum in late 2006 (WRS) or early 2007 (NINOs) in the UK and in 2006 in Ireland; however, they have been declining since then. The bulk of these applications are from Polish nationals, followed by Slovaks and Lithuanians. Note also that compared with the same period of 2007, there was an increase in the number of Hungarian nationals applying to WRS and for NINOs in 2008. This most probably reflected the worsening economic situation in Hungary. The figure also suggest some increase in the numbers of Bulgarian and Romanian nationals after the 2007 enlargement in spite of the transitional arrangements imposed on them.

13 Note that NINO and PPSN figures are directly comparable as social security number; whereas WRS constitutes a different measure. These figures are likely to overstate the actual migration numbers due to the likely temporary and seasonal nature of immigration from the new member states and a lack of incentives to deregister. 
Figure 5

Registered immigration in Ireland and the UK

UK Worker Registration Scheme applications, May 2004-December 2008

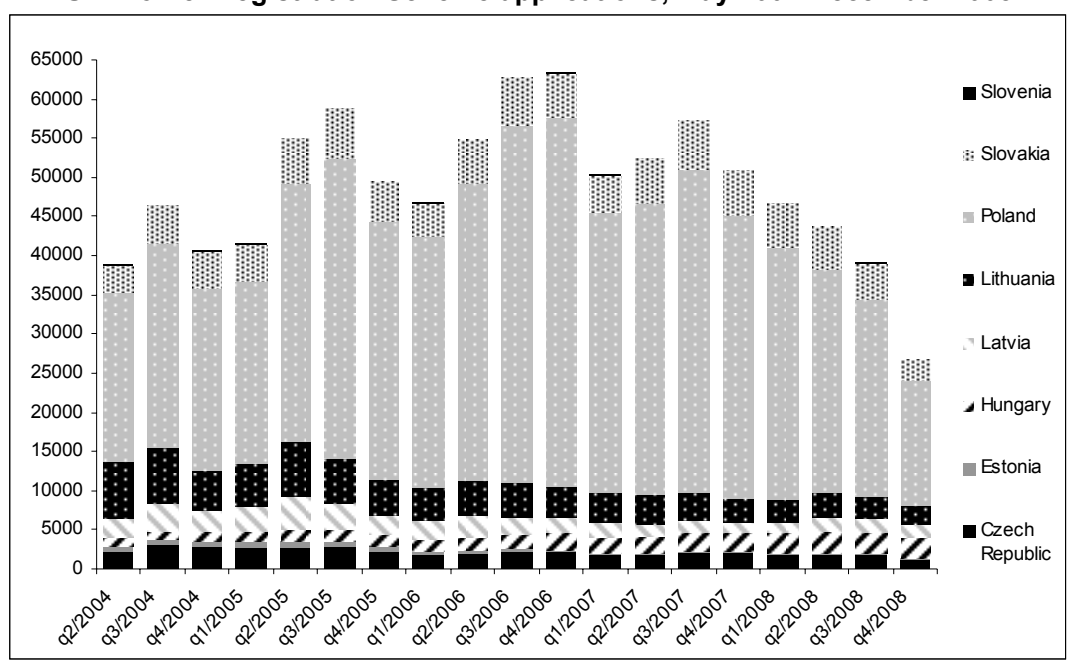

UK National Insurance numbers (in thousands), January 2002-September 2008

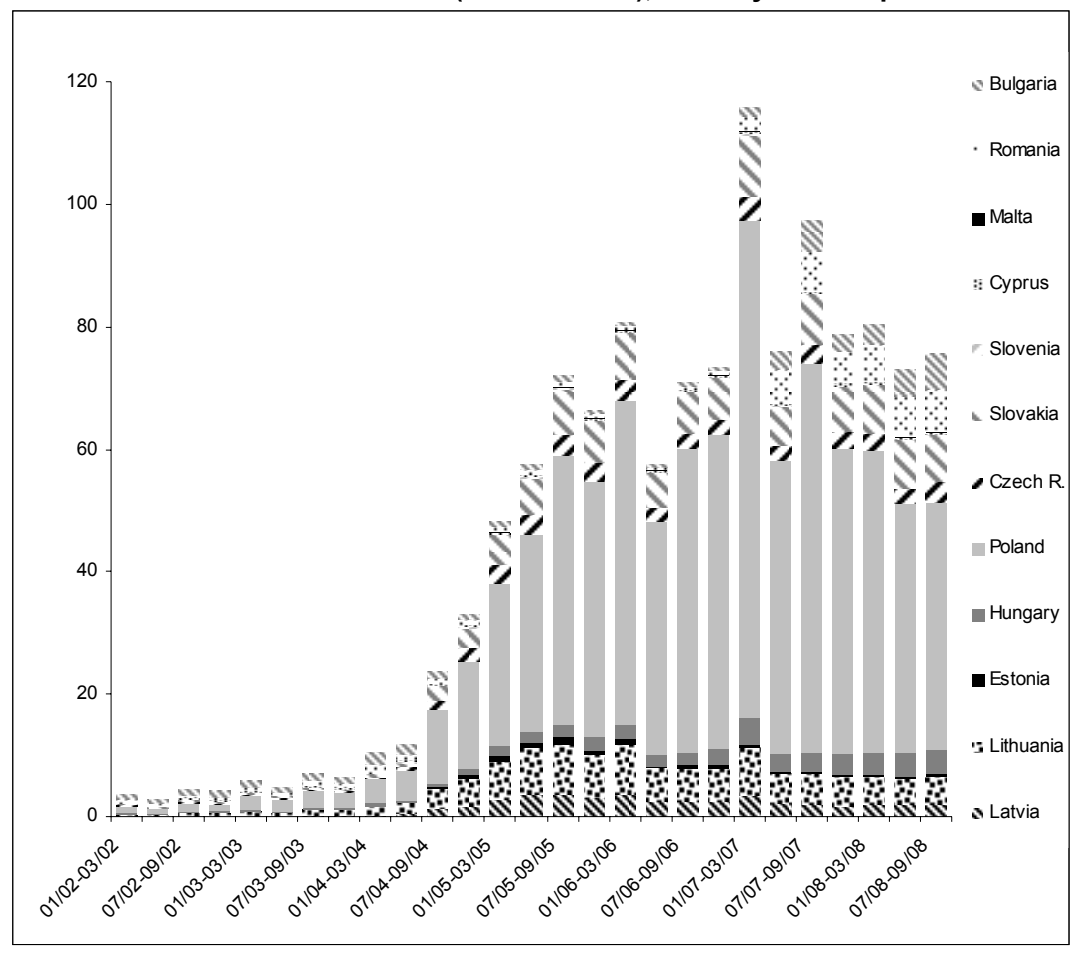




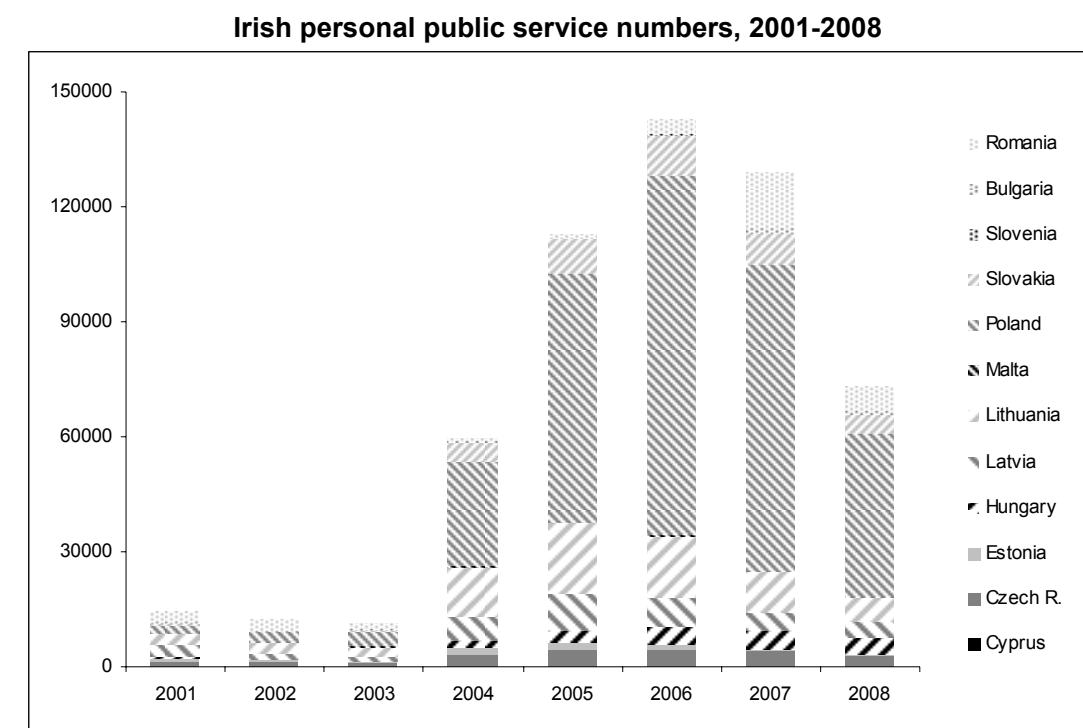

Source: UK WRS data are from Accession Monitoring Reports May 2004-June 2006, May 2004-December 2006, May 2004-December 2007, and May 2004-December 2008; UK NINO data are from Department for Work and Pensions online statistics:

www.dwp.gov.uk/asd/tabtool.asp\#ni_alloc;

Irish PPSN data are from the Department of Social and Family Affairs online statistics: www.welfare.ie/EN/Topics/PPSN/Pages/ppsn_all_2008.aspx

Notes: WRS show applicants approved for initial applications only.

Finally, valuable evidence is based on country-level studies. Gilpin et al. (2006) report that the number of nationals from the new member states increased substantially in the UK. Blanchflower and Lawton (2009) document that 812,000 workers from the new member states have registered to work in the UK since May 2004 till March 2008 under the Worker Registration Scheme, and there have been an additional 10,540 and 22,080 worker registrations from Bulgaria and Romania, respectively. The authors also argue that these numbers do not reflect actual immigration, since these people are temporary workers. However, the number of net migration from the eight new member states was much lower and was equal to 71,000 in 2006. This highlights the importance of the definition of migration. Doyle et al. (2006) document a small increase in immigration from the new member states in Sweden in 2005, while Gerdes and Wadensjö (2008) provide updated figures and show that the increase was larger in later periods. However, these immigrants still constitute a small part of the overall immigration to Sweden. Suggested reasons why immigration to Sweden did not increase by a larger extent include fewer job vacancies, less flexible labor markets and language issues. Doyle et al. (2006) document a remarkable increase in the number of foreigners in Ireland between 2003 and 2005, and the majority of this inflow in 2005 consisted of nationals from the new member states. 
Barrett et al. (2008) report that nationals from the new member states in Ireland in 2006 constituted 3\% of the country's population, an remarkable increase from fewer than 25,000 people in 2002. Finally, Brenke and Zimmermann (2007) document an increase in net immigration flows from the new member states into Germany despite the "closed door" policy.

\section{b. The Source Country Perspective}

To complete the picture of post-enlargement migration flows, we present available evidence from the source countries' perspective in this section. As shown in Figure 6, emigration to the EU15 has increased in all EU8 and EU2 countries since 2000. In 2007, the largest shares of emigrants in proportion to the home population were in Romania (7.2\%), Bulgaria (4.1\%), Lithuania (3.8\%) and Poland (3.4\%). According to the European Commission (2008b), between 2003 and 2007, 3.1\% of workingage Lithuanians moved to another EU country, followed by Cypriots (3.0\%), Romanians $(2.5 \%)$, Poles $(2.0 \%)$, Slovaks $(2.0 \%)$ and Bulgarians $(1.7 \%)$. Including those who emigrated more than four years ago, the countries with the highest share of emigrants were Romania, Cyprus, Bulgaria, Lithuania and Poland. For sake of comparison, the share of emigrants to the EU15 in 2007 was 7.1\% in Croatia and amounted to an extraordinary $25.5 \%$ in Albania, the country with the highest emigration rate in the region (Brücker and Damelang, 2009; Brücker et al., 2009).

Figure 6

Share of emigrants to the EU15 in the new member states

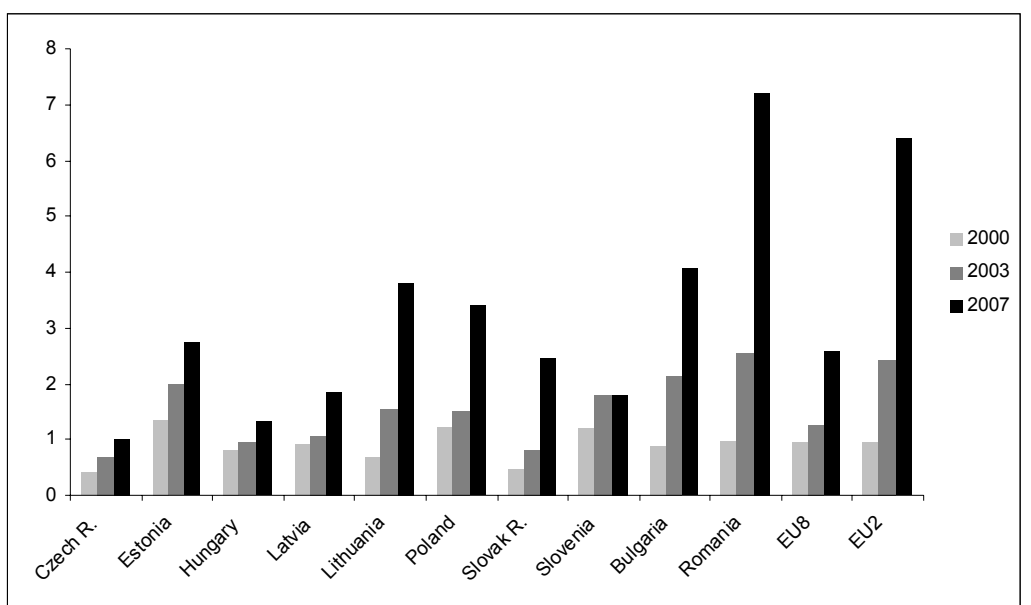

Source: Brücker and Damelang (2009), Table 6b.

Notes: In \% of the home population. Data are from National Population Statistics, Eurostat, LFS. 2000: without Austria and Luxembourg, 2000-2003: without Ireland, 2004-2007: Ireland included with structure of PPSN. See also notes in Brücker and Damelang (2009). 
Figure 7

Emigration rates to Germany correlated with GDP per capita/unemployment rates in the EU12

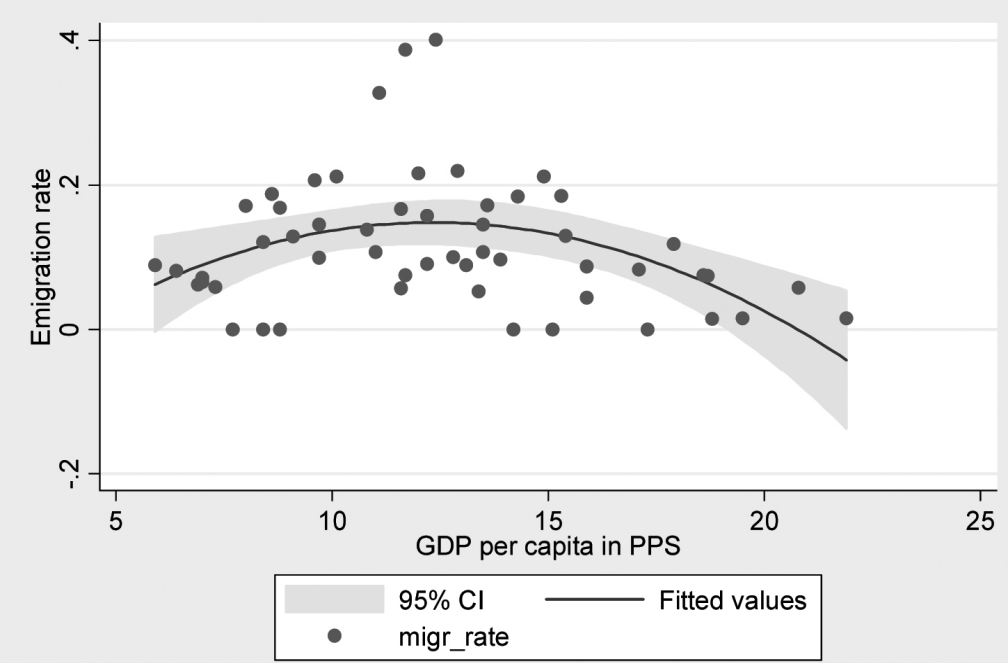

Adj.R2 $=0.16$
Yhat $=-0.17+0.051^{*}$ gdppc (t-value $\left.=2.98\right)^{* * *}-0.00002^{*}$ gdppc2 (t-value $\left.=-3.24\right)^{* * *} ; \mathrm{N}=54$

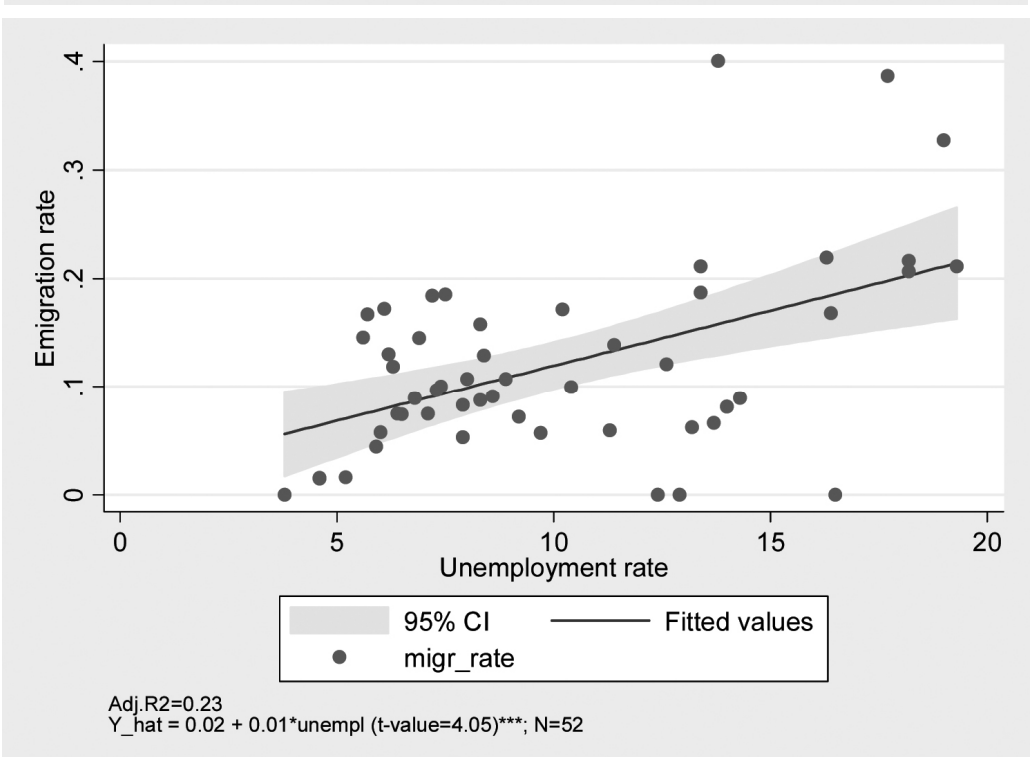

Source: Migration data are from the Eurostat online database available at

http://epp.eurostat.ec.europa.eu/portal/page? pageid=1090,30070682,1090 30298591\& dad=portal\& sc hema=PORTAL. Data on GDP per capita in PPS are from Eurostat Yearbooks 2006-2007 and 2008; data on unemployment and population are from Eurostat Yearbook 2008.

Notes: Migration rate is calculated as immigration from the respective sending country to Germany in \% of the sending country's population. Time period 1998-2006. 
Another interesting fact is that in 2004, the destination countries for emigrants from the new EU members changed, and Ireland and the UK became the preferred destinations after enlargement. For example, the main destination countries for emigrants from Lithuania in 2002 were Germany, Estonia, Russia, Ireland and the US; whereas they largely moved to the UK and Germany in 2004 (World Bank, 2006). Kadziauskas (2007) confirms that emigration from Lithuania has increased after enlargement and warns that the official emigration data might be severely understated.

A similar upward trend in emigration is apparent from Polish Labour Force Survey data, with 20\% more Poles staying abroad in 2004 than in 2003, which amounted to 250,000 people (World Bank, 2006). Kaczmarczyk and Okólski (2008) report that based on Polish LFS data, the number of Polish residents who stayed abroad for at least two months tripled from early 2004 to early 2007 from around 180,000 to around 540,000. Germany remains the most important destination country for immigrants from Poland (especially regarding seasonal migration), although its share is decreasing; while the importance of the UK and Ireland is increasing (World Bank, 2006; Frelak and Kazmierkiewicz, 2007; Kaczmarczyk and Okólski, 2008). The migrants are predominantly male, workoriented, young, relatively well-educated and tend to stay abroad for less than one year. The proportion of individuals with tertiary education is even larger among those migrating after enlargement, leading to an emergence of two distinct emigrants groups - low-skilled individuals from the periphery and high-skilled ones (Kaczmarczyk and Okólski, 2008).

Regarding potential macro-economic determinants of migration, Figure 7 is based on Eurostat data on gross immigration flows and examines whether a correlation exists between migration flows into Germany and the GDP per capita and unemployment rates of the sending countries. It shows that both GDP per capita and the unemployment rate are significant push-factors. Moreover, the concave pattern of GDP per capita is in line with the migration "hump" hypothesis (see Hatton and Williamson, 2005). ${ }^{14}$

\section{c. Who Migrated, and how Do They Fare?}

According to the European Commission (2008a, b), the post-enlargement migrants demonstrate greater labor market participation and have higher employment rates than the populations in either the sending or receiving countries.

14 Some caution, however, is needed when interpreting these results. Although there were large income and unemployment differences between old EU15 and new member states upon accession in 2004, unemployment has until recently been declining in the new member states. 
However, there are notable exceptions: recent EU8 immigrants in Germany exhibit lower employment and participation rates, but above average selfemployment rates (Brenke et al., 2009). The share of employed among EU8 migrants in the EU15 is larger for cohorts arriving after enlargement than for pre-enlargement migrants, and the shares of unemployed and inactive are correspondingly smaller for the former than for the latter (Brücker and Damelang, 2009). Interestingly, the employment rate is almost the same for pre- and postenlargement EU8 immigrants in Germany, while in the UK the share of postenlargement migrants in employment is much higher than that for preenlargement migrants. Note also that self-employment seems to have been used as a means to circumvent transitory arrangements in Germany (Brenke and Zimmermann, 2007; Brenke et al., 2009). Indeed, while the share of selfemployed among recent EU10 immigrants (those residing for four years or less) is low in the UK, around half of employed recent migrants from the EU2 in the UK and around $40 \%$ of recent EU10 migrants in Germany are self-employed (European Commission, 2008a).

Migrants from the new member states are also more likely to be overrepresented in low and medium-skilled sectors (such as manufacturing, construction, hotels and restaurants, but also agriculture and private households, especially for workers from EU2) and occupations in spite of the majority having a medium educational attainment and almost a quarter of EU8 immigrants possessing high education (European Commission, 2008b; Brücker and Damelang, 2009; Brücker et al., 2009). According to Brücker and Damelang (2009), in 2006 about $29 \%$ of the immigrant population (of working age) from Bulgaria and Romania had low educational attainment, compared to $17 \%$ from the EU 8 and $27 \%$ of natives from the EU15; the corresponding percentages with high education were 18, 22 and 27, respectively. The proportion of highly educated migrants from the EU8 in the EU15 is lower for cohorts that arrived after enlargement than for those who arrived before 2004, but also the share of the lessskilled has declined, resulting in a slight improvement of the average education level of the E8 immigrants. Interestingly, the proportion of EU8 postenlargement migrants in Germany with low education is substantially larger than the proportion of pre-enlargement migrants with low skills suggesting a negative selection of migrants; while in the UK, the proportion of those with low education is smaller and of those with higher education is larger after enlargement. In addition, migrants from the new member states are disproportionately young and there is also a relatively large share of females.

It is also important to note that a significant proportion of these migrants is likely to be of a temporary or seasonal nature. For example, $62 \%$ of workers registering in 2008 under the Worker Registration Scheme (WRS) in the UK intended to stay for less than three months, compared to $59 \%$ in 2007 and 55\% in 2006 
(Home Office, 2009). ${ }^{15}$ Germany also has a large number of migrants who are seasonal workers (see also European Commission, 2008b; Pollard et al., 2008).

Regarding country-level evidence from the UK, Ireland and Sweden, in most cases, the majority of EU8 migrants were found to be male, young, originating from Poland, the Baltic states and Slovakia, with relatively high or medium skill levels and concentrated in relatively low-skilled sectors, indicating such issues as downgrading and imperfect transferability of human capital. Despite their relatively high educational levels, in the UK these immigrants are concentrated in low-skilled sectors, such as hotels and restaurants, manufacturing and agriculture and in the low-skilled occupations (Gilpin et al., 2006; Drinkwater et al., 2006; Blanchflower et al., 2007; Blanchflower and Lawton, 2009). They are also more likely to be self-employed, have a higher propensity to work than natives and hold a qualification (Blanchflower et al., 2007; Blanchflower and Lawton, 2009). However, they were found to be relatively low paid. It is also argued that the higher unemployment rates for the most recent EU8 migrants arise largely because they are relatively young.

Doyle et al. (2006) study immigrants from the new member states in Sweden in 2005. They document that they have a higher labor force participation rate than nationals, and the majority work in hotels and restaurants, and in the construction and manufacturing sectors. Gerdes and Wadensjö (2008) report that these immigrants have relatively high education levels but lower employment rates than natives, and if they work, they self-select into relatively low-skilled jobs and sectors. Barrett and Duffy (2007) find that immigrants from the new member states in Ireland have the largest occupational disadvantage compared to other immigrants and natives. Furthermore, they show that the effect is largest for the post-enlargement arrivals and confirm the existence of "downgrading". According to Hughes (2007), there was a large increase of the EU10 employees in the construction sector in Ireland in the beginning of 2007. Barrett et al. (2008) provide the most recent analysis of EU8 immigrant performance in Ireland and show that the difference in earnings is either non-existent or low for people with low skill levels and for people at the lower end of the earnings distribution; while the difference is higher for those at the upper ends of the skills and earnings distributions. The authors suggest that the transferability of human capital is a crucial determinant of the immigrant-native earnings gap for these immigrants.

Building on Brenke and Zimmermann (2007), Brenke et al. (2009) provide evidence on the impact of immigrant flow from EU8 countries on the German labor market following EU enlargement, using more recent micro census data. As previously stated, Germany did not immediately open up its labor market to immigrants from the new member states. Nevertheless, their analysis confirms a

15 The temporal and seasonal nature of post-enlargement migration and the fact that there are no incentives to deregister may also explain the observed discrepancies between register and survey data. 
substantial inflow and suggests that the composition of EU8 immigrants has changed since EU enlargement. The majority of the new EU8 immigrants are male and young, and they are less educated compared to previous immigrant groups. They also find that recent EU8 immigrants are more likely to be selfemployed than employed as a wage earner. Furthermore, these recent EU8 immigrants earn less conditional on being employed or self-employed. The findings suggest that these recent EU8 immigrants are more likely to compete for low-skilled jobs with immigrants from outside of Europe and not with German natives. While Germany needs high-skilled immigrants, the analysis suggests that the new EU8 immigrants only replace non-EU immigrants in low-skilled jobs. These results underline the importance of more open immigration policies targeting high-skilled immigrants. The current German migration policy not only fails to attract the required high-skilled workforce, but also cannot avoid attracting the low-skilled immigrants.

The reasons for migration from the new to the old member states and the barriers migrants face are important factors that shape the nature of east-west migration in Europe. Consistently with the above evidence, employment-related factors were found to be the most important mobility motives for these emigrants (Fouarge and Ester 2007a, b; Bonin et al. 2008). The intentions to learn English may also constitute a reason for emigrating as shown for migrants to the UK by Anderson et al. (2006), and Pollard et al. (2008). East Europeans were generally found to be unhappy with their lives, dissatisfied with their salaries and working conditions, concerned about the availability of good jobs and insecure about their current jobs. All these factors further contributed to reasons to move abroad (Blanchflower and Lawton, 2009; Blanchflower et al., 2007). A similar picture emerges from studies in the new member states. Kadziauskas (2007) reports that in Lithuania, a country with one of the largest emigration rates, $90 \%$ of the respondents name low salaries as the main motive to seek employment abroad. On the other hand, language and cultural barriers play key roles as factors deterring intra-European migration. Furthermore, worries about finding a (suitable) job and the expected loss of social contacts with family or friends also matter (Fouarge and Ester, 2007a; Bonin et al., 2008).

Is it likely that migration intentions in the new member states and thus actual migration will decline in the future? The latest available evidence shows that immigration from the new member states to the EU15 has risen after enlargement, in particular in Ireland and the UK, and these new networks may in turn trigger future migration. However, the inflows of nationals from the new member states to the UK and Ireland also appear to have slowed down in 2007 and 2008 (see Figure 5 and European Commission, 2008b). Moreover, there does not seem to be a simple relation between the transitional arrangements and migration flows. On the one hand, the proportion of individuals intending to emigrate after the 2004 enlargement was found to be larger in the new member states than in the EU15; 
whereas it was smaller before the enlargement (see Fouarge and Ester, 2007a; Zaiceva and Zimmermann, 2008). ${ }^{16}$ This may suggest that with open borders an increasing number of individuals in the EU8 are willing to try their luck abroad, since the option to return or migrate again is now always available. However, it may also be due to the transitory enlargement-related shock and euphoria, which may fade away over time. A number of additional factors could influence future east-west migration: growth in the new member states; income convergence; falling unemployment rates; expected appreciation in their exchange rates in the long term; new vacancies and skills shortages in these countries, combined with an ageing population and remaining cultural barriers. A recent European Commission report points out that "a further surge of labour mobility from the new Member States seems unlikely" (European Commission, 2008a, p. 8). Indeed, Figure 8 shows that in 2006 although around $15 \%$ of respondents in the new member states think about emigrating to another EU country in order to work "but haven't decided yet", 13\% have already "given up the idea". The data from the 2007 Eurobarometer on intentions to migrate abroad, although not directly comparable to earlier waves, seem to indicate that moving intentions were on average lower in 2007 than they were in 2005, and the largest decline occurred in the Baltic States (Bonin et al., 2008). Interestingly, cross-border moving intentions in 2007 were highest in Bulgaria and Romania.

Figure 8

Intentions to migrate for work

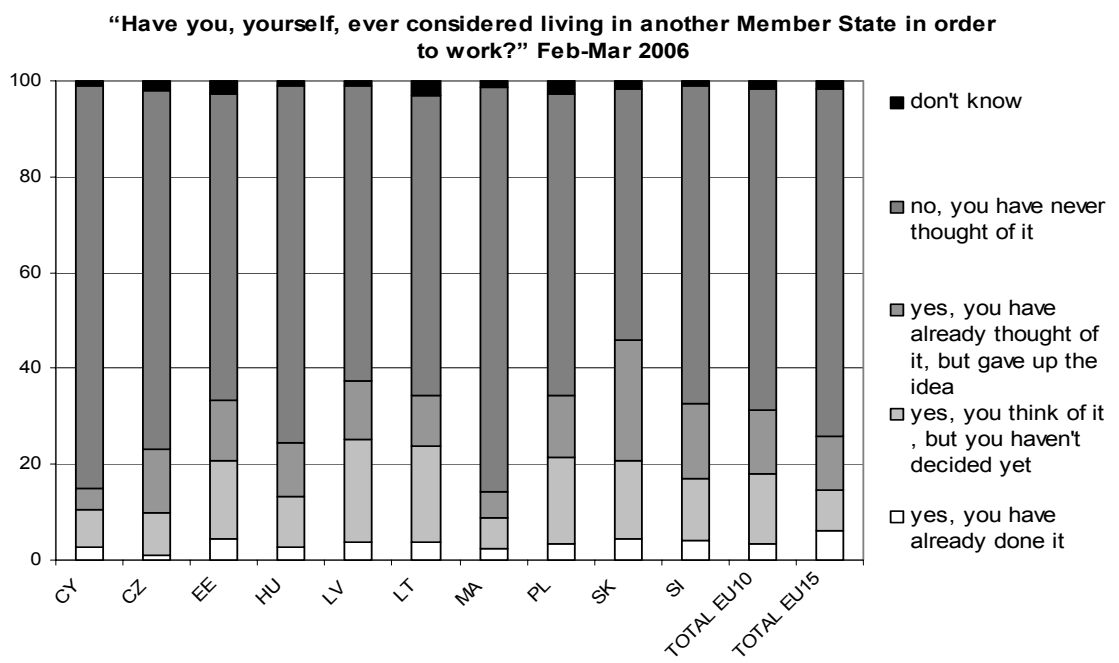

Source: Own tabulations from the Eurobarometer EB 65.1.

16 Note, however, that the questions were asked in a slightly different manner before and after enlargement, which may partly account for the documented differences. 
Box: Air passengers traveling to and from new EU member states via London

Since mid-1990s there has been an increase in the number of air passengers at London airports traveling to and from the new member states. Furthermore, the most dramatic increase occurred after 2004 (Figure B1). This trend is clear if London airports are studied with the focus on passengers to and from Poland (Figures B2 and B3). In 1996. Heathrow was the most relevant airport and the number of passengers was around 297,000; however by 2000 the number of passengers had increased to around 474,000, and by 2007 Gatwick, Heathrow, Stansted and Luton had reported the total number of passengers to and from Poland was close to 3 million. There was also an increase in the number of connections between Poland and London and by 2007 ten Polish airports had established connections with four London airports. While the advent of low-cost airlines contributed to this development, the demand factors are undeniable. One should also note that these numbers reflect not only the increased migration to and from the UK, but also an increase in tourism. From another perspective, the importance of distance in monetary terms is declining (see also Brücker and Damelang, 2009 and Brücker et al., 2009 for documenting "the eroding role of distance"). It used to cost almost the same amount of money for a person to travel from a peripheral town of Rzeszów in south-east Poland to London on a low-cost air carrier (around 30 euros, 1 hour and 35 minutes, one way) as to go by train to Warsaw (around 26 euros and 5 hours and 20 minutes, one way) and somewhat less if traveling to Warsaw by bus (around 16 euros and 4 hours and 45 minutes, one way). ${ }^{17}$

Figure B1

Number of air passengers between London airports and new member states

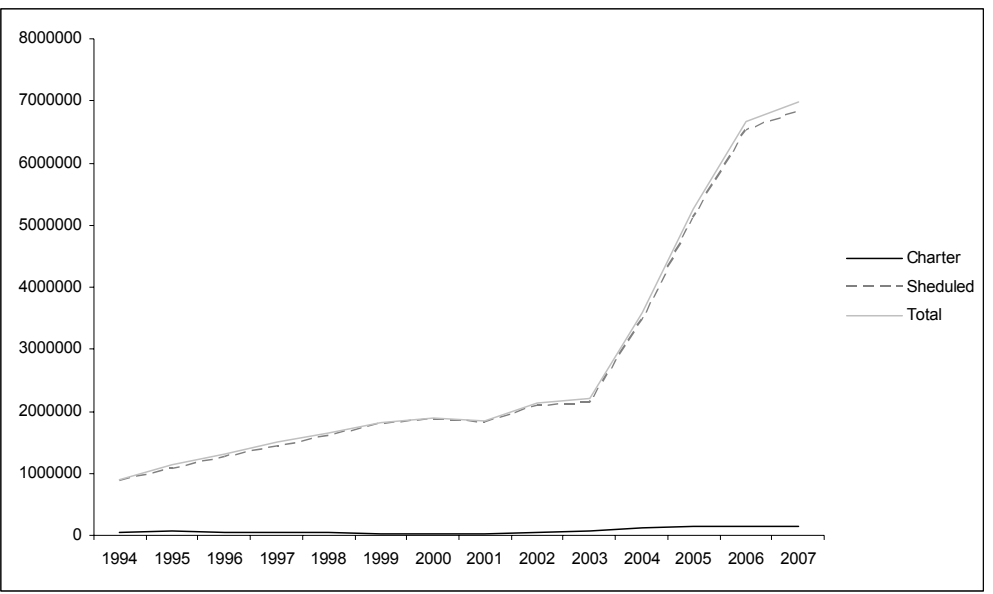

Source: Own calculations from UK Airport Statistics, Table 121 Intl Air Pax Route Analysis (various years):

www.caa.co.uk/default.aspx ?catid=80\&pagetype $=88$ \& pageid $=3 \&$ sglid $=3$

Notes: Number of passengers traveling to or from London Airports to or from the following countries: Bulgaria, the Czech Republic, Estonia, Hungary, Latvia, Lithuania, Poland, Romania, Slovakia, Slovenia. 
Figure B2

Total air passenger traffic at London airports to and from Poland

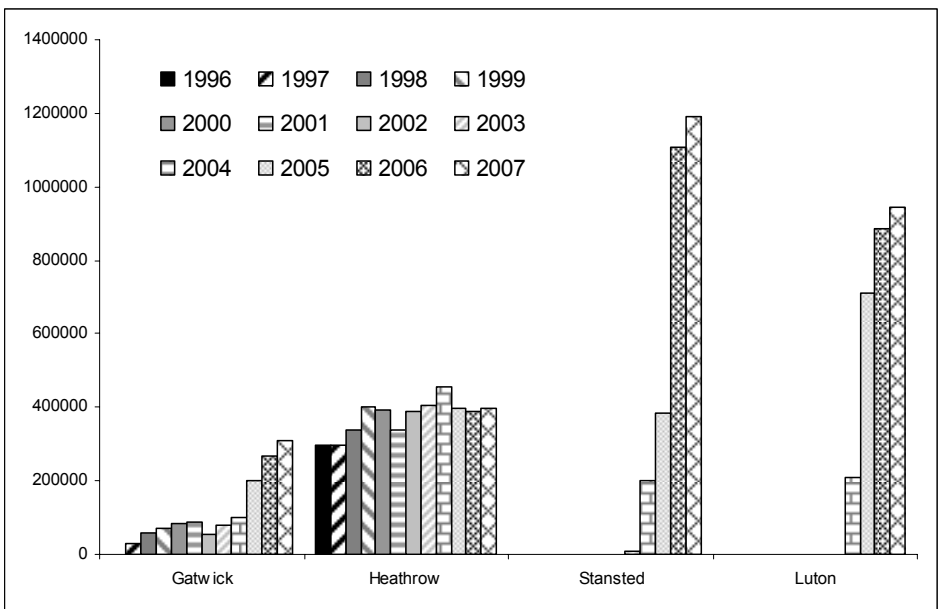

Source: Own calculations from UK Airport Statistics, Table 121 Intl Air Pax Route Analysis (various years):

www.caa.co.uk/default.aspx?catid=80\&pagetype $=88$ \&pageid $=3 \&$ sglid $=3$

Figure B3

Trends in the numbers of air passengers at London airports to and from Poland

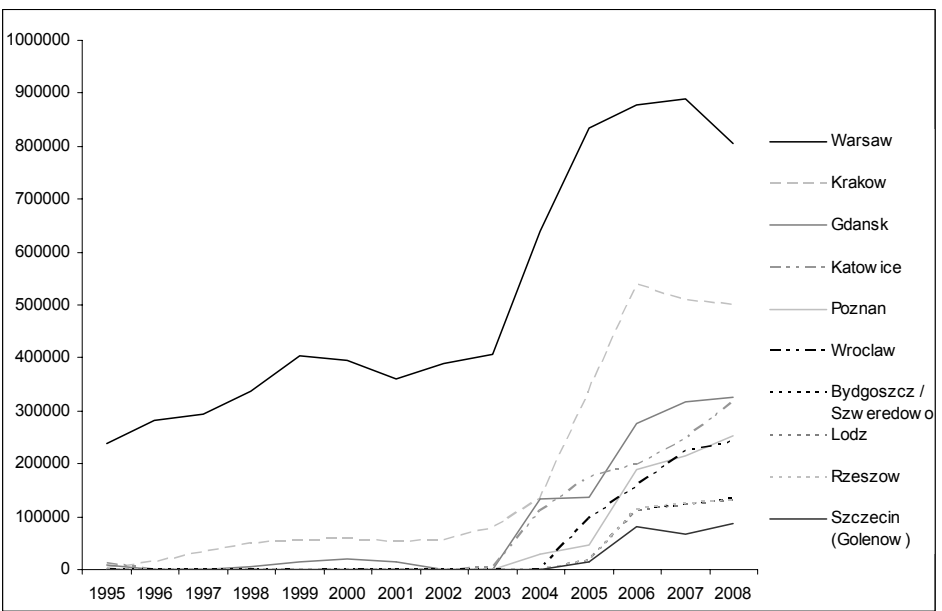

Source: Own calculations from UK Airport Statistics, Table 121 Intl Air Pax Route Analysis (various years):

www.caa. co.uk/default.aspx $?$ catid=80\&pagetype $=88 \&$ pageid $=3 \&$ sglid $=3$

17 This average one-way price is calculated for a week between February 2, 2009, and February 8,2009 . These requests were made in November 2008. The time reported is the fastest available. 


\section{The Impact of Post-Enlargement Migration Flows:} First Evidence

\section{a. The Destination Countries}

The possible negative impact of immigration on labor markets and welfare in destination countries was one of the main reasons for introducing the transitional arrangements for workers from the new member states. Were these concerns justified or exaggerated? While it is still too early to provide a complete answer, some preliminary evidence already exists. In order to assess the impact on destination countries, we first examine the aggregate labor market statistics to identify the main trends before and after the recent enlargements.

Figures 9-14 present labor market statistics for the EU15 as well as for Ireland, Sweden and the UK. It can be seen from Figure 9 that there is no evidence of a significant slow-down of employment growth after the 2004 enlargement until at least 2007. The exception is Ireland, where employment growth started to decline during the middle of 2005 from very high levels. Regarding the aggregate unemployment rate, Figure 10 shows that until recently there had been a general decline in Germany and the EU15 after the 2004 enlargement. The situation differs in the three countries that opened up their labor markets in 2004: the unemployment rate in Sweden increased in 2005 but afterwards declined to pre-enlargement levels, and increased once again in 2008. The declining trend in the UK reversed in the middle of 2005 and then stabilized at a higher level. It had been slightly declining since mid2006 until the recent increase. The trend in Ireland was a slightly declining unemployment rate until 2005, fluctuating between 4 and 5\% between 2005 and 2007 , which started to pick up more recently. Therefore, one cannot identify a consistent (and adverse) reaction pattern of unemployment with immigration.

Figures 11 and 12 show that there was demand for new labor in the destination countries because the 2007 job vacancy rates in the UK and Sweden were the same if not larger than before the 2004 enlargement. Even in manufacturing, a sector with a high concentration of accession country citizens, the available data for the UK show that after an initial decline immediately after enlargement, the job vacancy rate was higher at the end of 2007 than before enlargement. Declining job vacancy rates can be observed in all the time series after around 2007. Similarly, earnings data reveal that in the period following the 2004 enlargement up until recently nominal wages and salaries (as part of the labor cost index) continued to grow even in manufacturing in the UK, Ireland and Germany (see Figures 13 and 14). ${ }^{18}$

18 Note, however, that these are nominal values. 
Figure 9

Employment growth in selected old member states

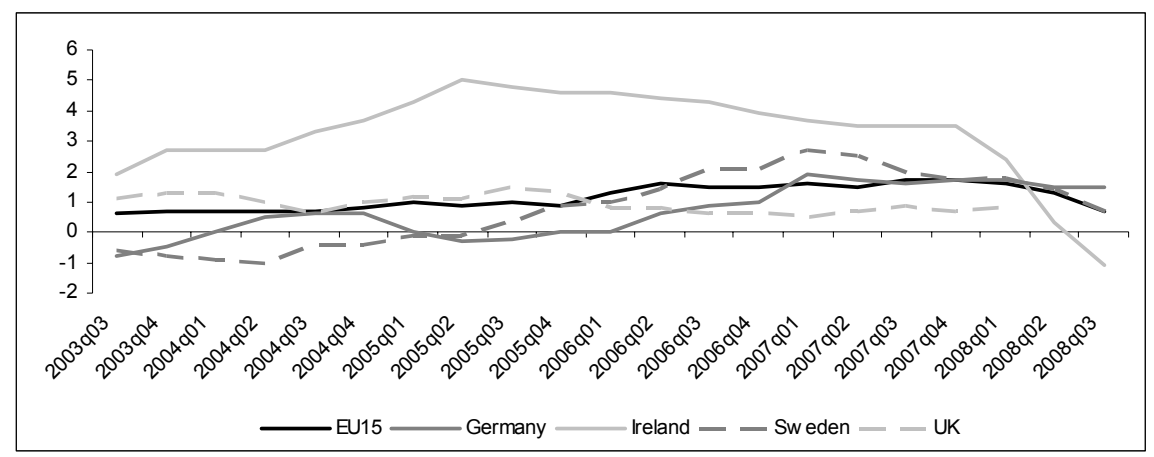

Source: Own calculations based on data from the Eurostat online database for Population and Social Conditions / Labour Market / Employment and Unemployment (Labour Force Survey):

http://epp.eurostat.ec.europa.eu/portal/page?_pageid=1090,30070682,1090_30298591\&_dad=portal\&_sche ma=PORTAL

Notes: The indicator employment growth gives the change in percentage from one year to another of the total number of employed persons on the economic territory of the country or the geographical area. The indicator is based on the European System of Accounts.

Figure 10

\section{Unemployment rates in selected old member states}

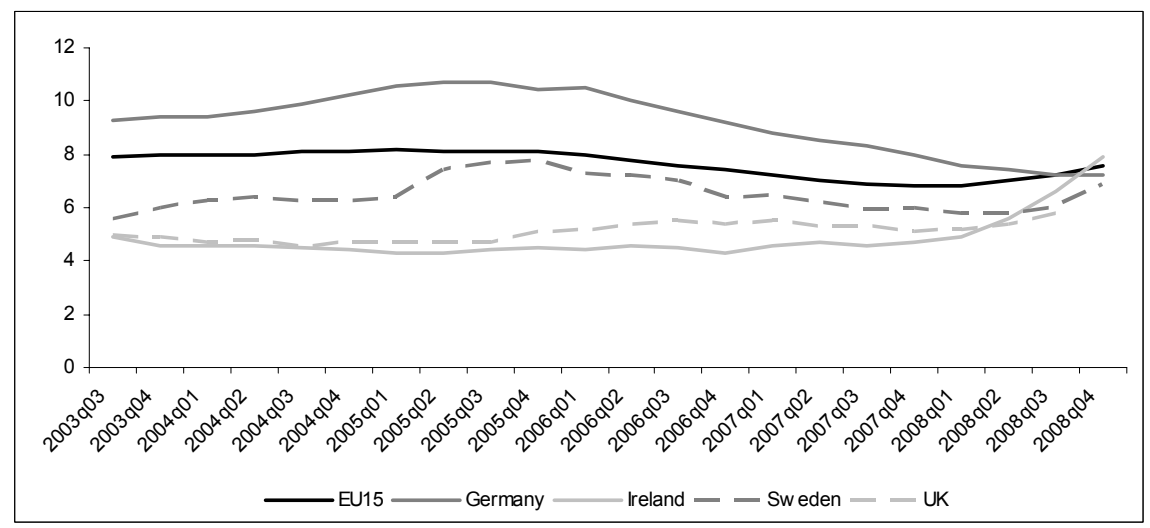

Source: Own calculations based on data from the Eurostat online database for Population and Social Conditions / Labour Market / Employment and Unemployment (Labour Force Survey):

http://epp.eurostat.ec.europa.eu/portal/page?_pageid=1090,30070682,1090_30298591\&_dad=portal\&_sche ma=PORTAL

Notes: Seasonally adjusted. Unemployment rates represent unemployed persons as a percentage of the labor force. The labor force is the total number of people employed and unemployed. Unemployed persons comprise of people aged 15 to 74 who were: a) without work during the reference week; b) currently available for work, i.e. were available for paid employment or self-employment before the end of the two weeks following the reference week; c) actively seeking work, i.e. had taken specific steps in the four week period ending with the reference week to seek paid employment or self-employment or who found a job to start later, i.e. within a period of at most three months. 
Figure 11

Job vacancy rate in selected old member states

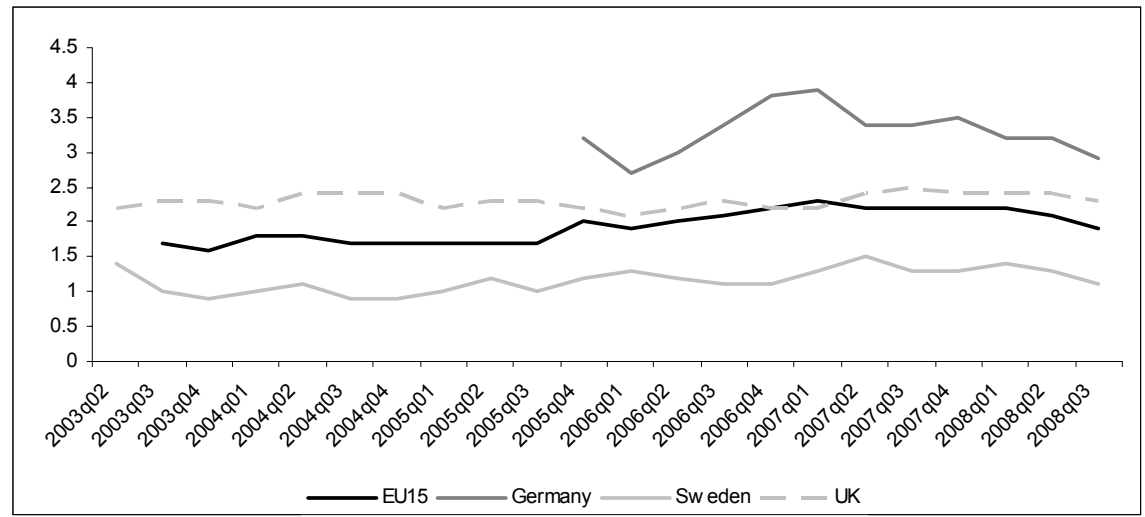

Source: Own calculations based on data from the Eurostat online database for Population and Social Conditions / Labour Market / Job Vacancy Statistics available at:

http://epp.eurostat.ec.europa.eu/portal/page?_pageid=1090,30070682,1090_30298591\&_dad=portal\&_sc hema=PORTAL

Notes: In \%. A job vacancy is defined as a post (newly created, unoccupied or about to become vacant), for which the employer is taking active steps to find a suitable candidate from outside the enterprise concerned and is prepared to take more steps; and which the employer intends to fill either immediately or in the near future. The data for Ireland are not available. For EU15 and Germany, provisional values are reported.

\section{Figure 12}

\section{Job vacancy rate in manufacturing in selected old member states}

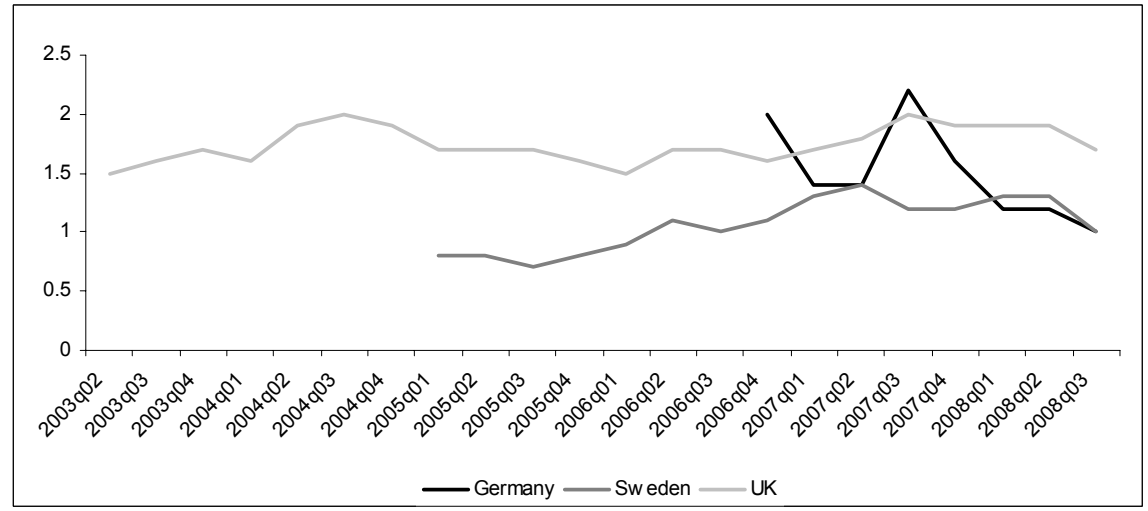

Source: Own calculations based on data from the Eurostat online database for Population and Social Conditions / Labour Market / Job Vacancy Statistics available at:

http://epp.eurostat.ec.europa.eu/portal/page?_pageid=1090,30070682,1090_30298591\&_dad=portal\&_sc hema=PORTAL

Notes: In \%. For definitions, see notes to Figure 11. The data for Ireland and EU15 are not available. For Germany, provisional values are reported. 
Figure 13

Labor cost index: wages and salaries in selected old member states

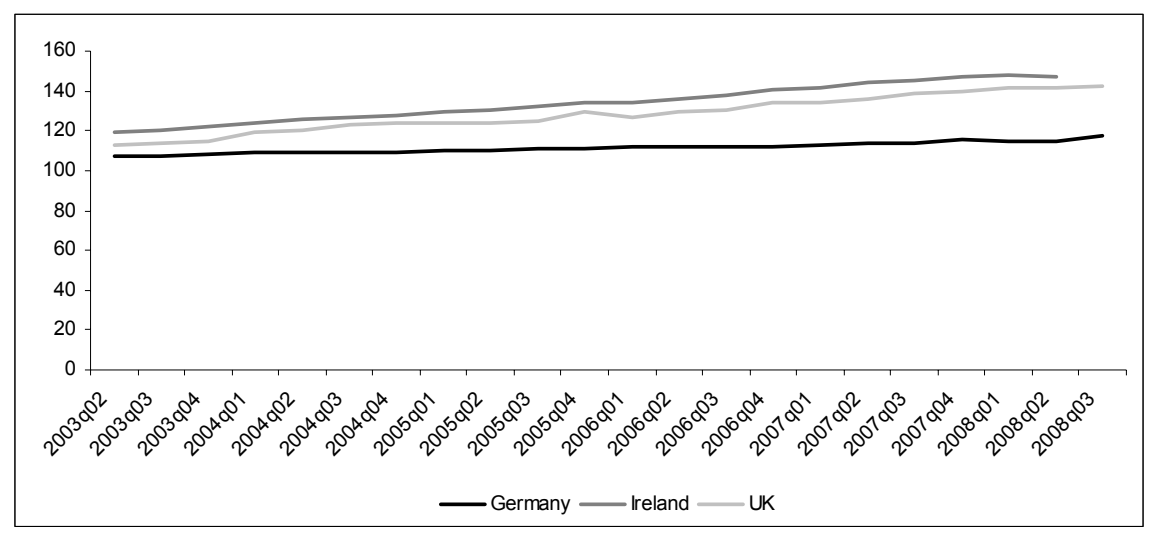

Source: Own calculations based on data from the Eurostat online database for Population and Social Conditions / Labour Market / Labour Costs available at:

http://epp.eurostat.ec.europa.eu/portal/page?_pageid=1090,30070682,1090_30298591\&_dad=portal\&_sc hema=PORTAL

Notes: Index $2000=100$. Wages and salaries in industries and services excluding public administration, seasonally adjusted and adjusted by working days, nominal value. Data for EU15 are not available.

Figure 14

Labor cost index: wages and salaries in manufacturing in selected old member states

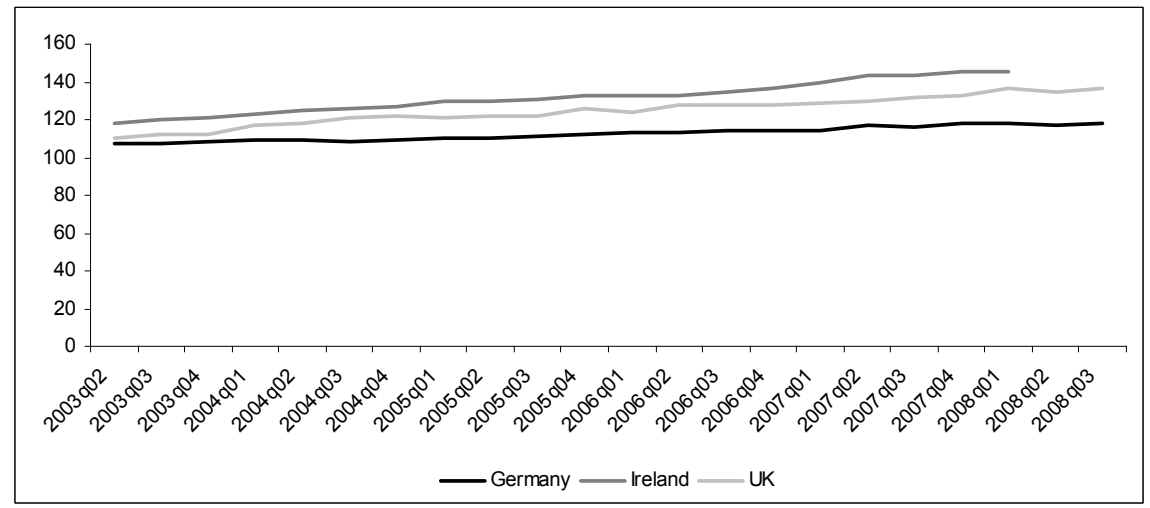

Source: Own calculations based on data from the Eurostat online database for Population and Social Conditions / Labour Market / Labour Costs available at:

http://epp.eurostat.ec.europa.eu/portal/page?_pageid=1090,30070682,1090_30298591\&_dad=portal\&_sc hema=PORTAL

Notes: Index $2000=100$. Wages and salaries in manufacturing seasonally adjusted and adjusted by working days, nominal value. Data for EU15 are not available. 
While causal interpretations of these findings would be misleading, the stability of the observed aggregate variables around the time of the 2004 EU enlargement is consistent with the hypothesis that there were not any significantly negative impacts on the labor markets in the receiving countries. This is true even for the UK and Ireland, where the inflows of EU8 immigrants were the largest. A general caveat of this analysis is that that aggregate data may suffer from aggregation bias and the impact of immigration from the new member states may be higher for the local labor markets, i.e. certain skill groups, sectors or occupations.

The available literature also suggests that immigration from the new member states has hitherto had little, if any, impact of on wages and employment and has had no negative impact on the welfare systems in the receiving countries. Several studies find very small or no impact of the recent immigration from the new member states on the UK unemployment rate or wages, even after controlling for potential observable and unobservable confounding factors in an econometric analysis (see Gilpin et al., 2006; Blanchflower et al., 2007; Lemos and Portes, 2008). Blanchflower and Lawton (2009) suggest that recent immigration from the EU8 "appears to have had some direct effect on the relative wages of the least skilled" (p. 15, see also Blanchflower and Shadforth, 2009). It is rather the "fear of unemployment" that has risen in response to immigration from the new member states (Blanchflower and Shadforth, 2009). The number of EU8 nationals applying for UK social benefits is low, and child benefits constitute the largest category. On the macroeconomic side, Blanchflower et al. (2007) find no evidence that the rise in the UK unemployment rate is related to structural factors and argue that recent immigration helps to suppress inflationary pressures.

The post-2004 immigrants from the EU10 in Sweden are slightly overrepresented in social assistance, but underrepresented in other income transfer programs, and the number of recipients of child allowance is also low among these immigrants (Gerdes and Wadensjö, 2008). ${ }^{19}$ Regarding Ireland, no evidence of "welfare tourism" is found, and it is argued that the immigration was primarily demand-driven (Doyle et al. 2006; Hughes, 2007; Doyle, 2007). Some decrease in earnings growth rates of some employees in Ireland is documented (Doyle et al. 2006), which has increased thereafter (Hughes, 2007). Although several cases of displacement of Irish workers by EU8 citizens earning lower wages are documented, on aggregate, displacement does not appear to be a source of disturbance, since the aggregate unemployment rate has remained constant after enlargement, and even if Irish workers have been displaced in some sectors, they have most probably moved to other better-paying jobs (Doyle et al., 2006; Hughes, 2007). Moreover, vacancies data show that the demand for labor has remained strong after enlargement.

19 See also Doyle et al. (2006) and Wadensjö (2007). 
Brücker et al. (2009) find that the immigration from the new member states during 2004-2007 has decreased EU15 average wages by only $0.09 \%$ in the short run (compared to a hypothetical situation of what they would have been without the additional mobility from the EU8), and have no impact in the long-run. Average EU15 unemployment rates were found to increase in the short-run by 0.06 percentage points and by 0.02 percentage points in the long-run (see also European Commission 2008a, b). Analogously, Baas et al. (2009) calibrate the decline in wages to be $0.09 \%$ and an increase in unemployment by 0.06 percentage points in the EU15 in the short run with no significant effects in the long run.

The recent east-west migration has several additional impacts that are worth mentioning. First, post-enlargement mobility has substantial positive effects for the EU as a whole in terms of GDP, GDP per capita and productivity; and a somewhat smaller effect for employment in the long run (European Commission, 2008a, b, 2009; Baas et al., 2009). For example, Brücker et al. (2009) find that post-enlargement immigration from the EU8 increases the GDP (and GDP per capita) of the enlarged EU by about $0.1 \%$ in the short run and by about $0.2 \%$ in the long run. The old member states also experience an increase in GDP, but their GDP per capita decreases in the short run due to decreased productivity and wages (D'Auria et al., 2008; Brücker et al., 2009). The effects are the opposite in the new member states: GDP declines, but there are gains for real wages, productivity and GDP per capita.

It is also likely that skilled immigration from the new member states may improve the inequality situation in the old EU15 in the long run. Using data on immigration to OECD countries, Kahanec and Zimmermann (2008) provide empirical evidence on the positive relationship between high-skilled immigration and economic equality in the destination countries. In addition, it is known that immigration may alleviate the demographic burden and, especially skilled immigration, may relieve the pressure placed due to an ageing population in the old EU15 (see Bonin et al., 2000 for an analysis of the fiscal impact of earlier immigration in Germany). Since immigrants from the new member states are predominantly young and relatively skilled (although they seem to self-select into relatively lowskilled occupations), they may decrease the fiscal burden of future resident generations; however, this effect depends on immigrants' remaining lifetime net payments to the public sector in the host country.

Overall, based on the early evidence, the World Bank (2006, p.1) concludes that: "Evidence from the receiving countries indicates that fears of massive inflows of workers and devastating impacts on receiving labor markets were unfounded, since inflows of foreign workers have generally supplemented rather than replaced domestic labor and helped sustain solid economic growth, while at the same time keeping local wages stable." The European Commission reports (see European Commission, 2006a, b, 2008a, b, 2009) also conclude that the im- 
pacts of the recent east-west mobility on labor markets in receiving countries have been non-negative on average, or even positive, and have not led to any serious disturbances in the labor markets. Moreover, these immigrants seem to have helped improve labor market efficiency by alleviating labor shortages in sectors and occupations with the excess demand for labor that could not be satisfied by the native labor force. They also contributed to easing inflationary pressures and to increase economic growth in the receiving countries.

\section{b. The Source Countries}

An important part of the picture of the effects of post-enlargement migration is the situation in the sending countries. Evidence reviewed above suggests that several new member states have experienced significant outflows of relatively young and skilled people. Is brain drain from the new member states indeed a worrisome issue? What are the demographic and economic impacts of the post-enlargement emigration in the EU8 and EU2, which are still troubled by post-transition structural and institutional weaknesses?

Figure 15

Unemployment rate in the new member states

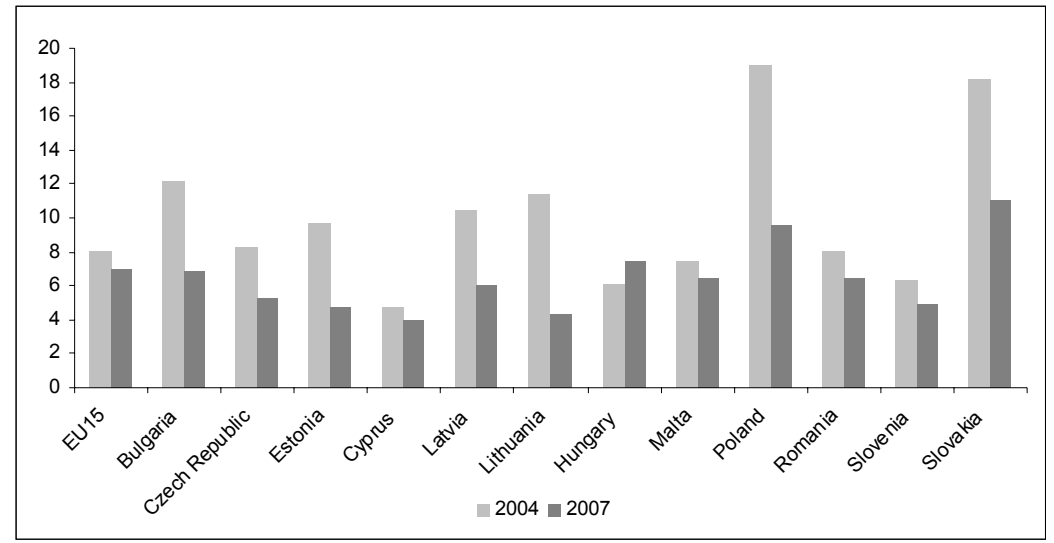

Source: Authors' calculations based on data from the Eurostat online database for Population and Social Conditions / Labour Market / Employment and Unemployment (Labour Force Survey) available at:

http://epp.eurostat.ec.europa.eu/portal/page?_pageid=1090,30070682,1090_30298591\&_da $d=$ portal\&_schema=PORTAL

Notes: Annual data, not seasonally adjusted. Unemployment rates represent unemployed persons as a percentage of the labor force.

As discussed above, labor migration from the new member states has increased since enlargement. The significant outflows of predominantly young and skilled 
individuals may have negative long-run impacts on these countries' economic growth, demographic situation and public budgets. For example, it has been estimated that the elderly dependency ratio will more than double by 2050 in Lithuania, and without fundamental changes (such as adjusting benefits, the age of eligibility or promoting immigration) the social security system may fail entirely (Kadziauskas, 2007). A significant decline in population and labor force has also been forecasted for Poland, which would place a serious burden on its labor market and public budgets over the next 50 years (Kaczmarczyk and Okólski, 2008). This shrinking share of working age population is also likely to drive down the future emigration potential from the new member states.

Figure 16

Employment growth rates in the new member states

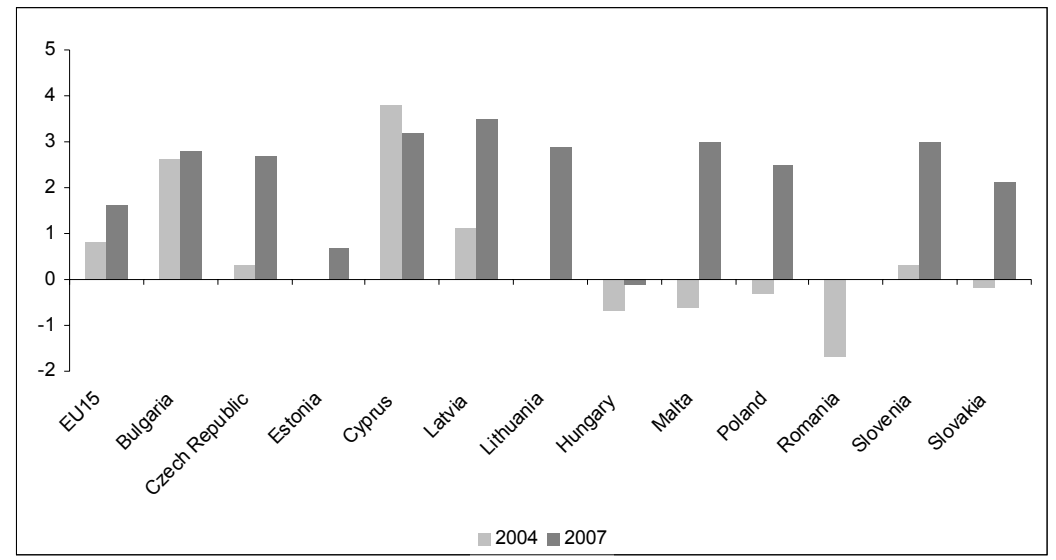

Source: Authors calculations based on data from the Eurostat online database for Population and Social Conditions / Labour Market / Employment and Unemployment (Labour Force Survey) available at:

http://epp.eurostat.ec.europa.eu/portal/page?_pageid=1090,30070682,1090_30298591\&_da d=portal\&_schema=PORTAL

Notes: The indicator employment growth gives the change in percentage from one year to another of the total number of employed persons on the economic territory of the country or the geographical area. The indicator is based on the European System of Accounts.

Emigration from the new EU members goes hand in hand with a decreasing unemployment rate and an increasing employment growth rate, the number of vacancies rose until the last quarter of 2007 (see Figures 15-17), all indicating potential labor shortages. Indeed, emigration may exacerbate structural weaknesses in national labor markets, as there are shortages of highly skilled specialists in a number of sectors (World Bank, 2006). There were around 12,000 unfilled vacancies in Lithuania at the end of 2005, and labor shortages were particularly large in manufacturing and trade sectors (Kadziauskas, 2007). There were particularly significant shortages of workers in Poland in manufacturing, trade, hotels and restaurants, and construction (Kaczmarczyk and Okólski, 2008). The mismatch between 
vacancies and workers is also often present. One of the consequences is increasing immigration in the new member states due to the increased demand for immigrant labor. In Poland, for example, the number of immigrants in 2004 was the highest since 1960, and the main countries of origin in 2003 were Ukraine, Belarus and Russia (Frelak and Kazmierkiewicz, 2007; Iglicka, 2005). This may be a sign of new migration patterns when citizens of new member states are substituted by non-EU immigrants.

Figure 17

Job vacancy rate in selected new member states
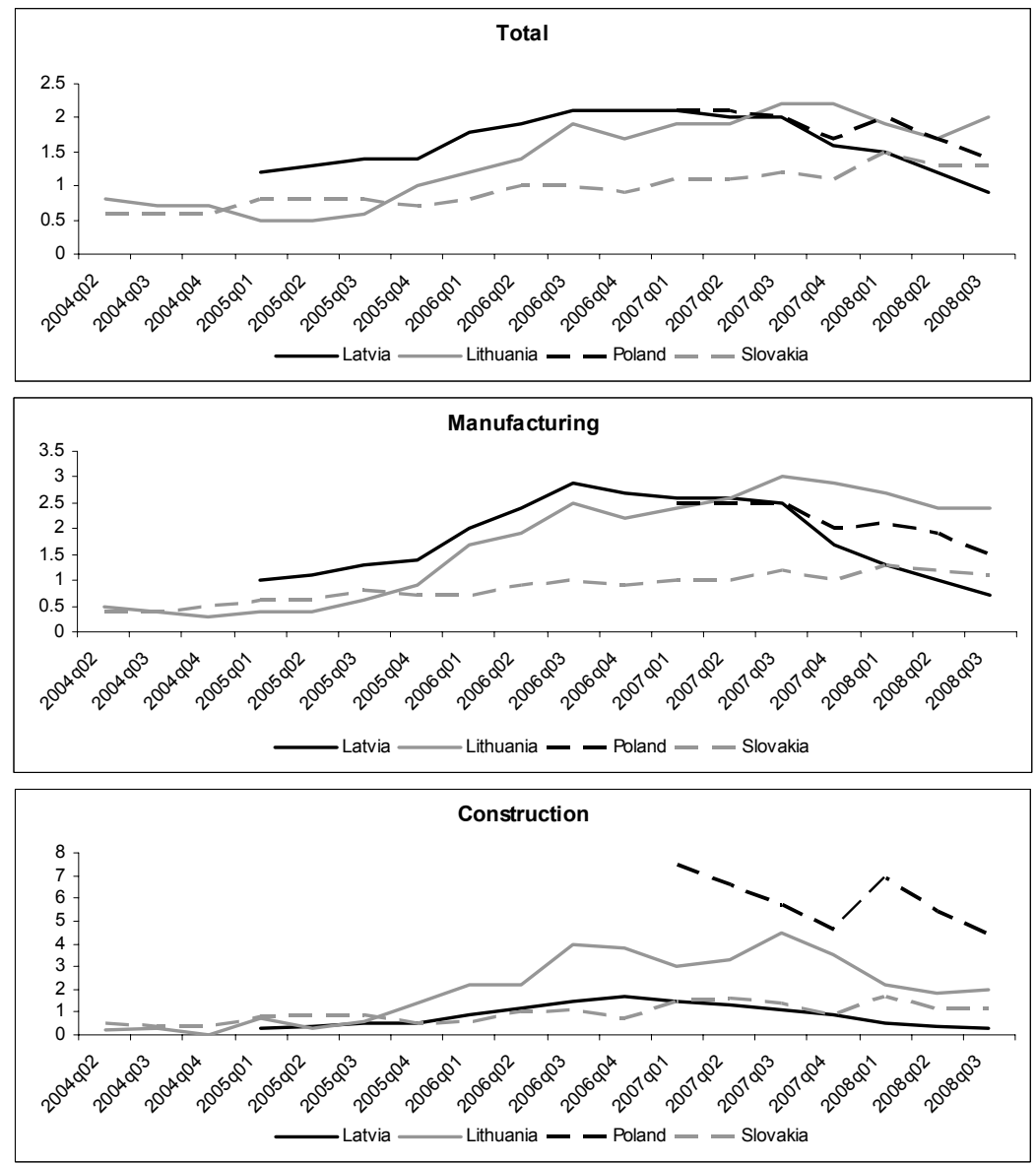

Source: Authors' calculations based on data from the Eurostat online database for Population and Social Conditions / Labour Market / Job Vacancy Statistics available at: http://epp.eurostat.ec.europa.eu/portal/page?_pageid=1090,30070682,1090_30298591\&_da d=portal\&_schema=PORTAL

Notes: In \%. 
Figure 18

Average monthly earnings in industry and services (in euros)

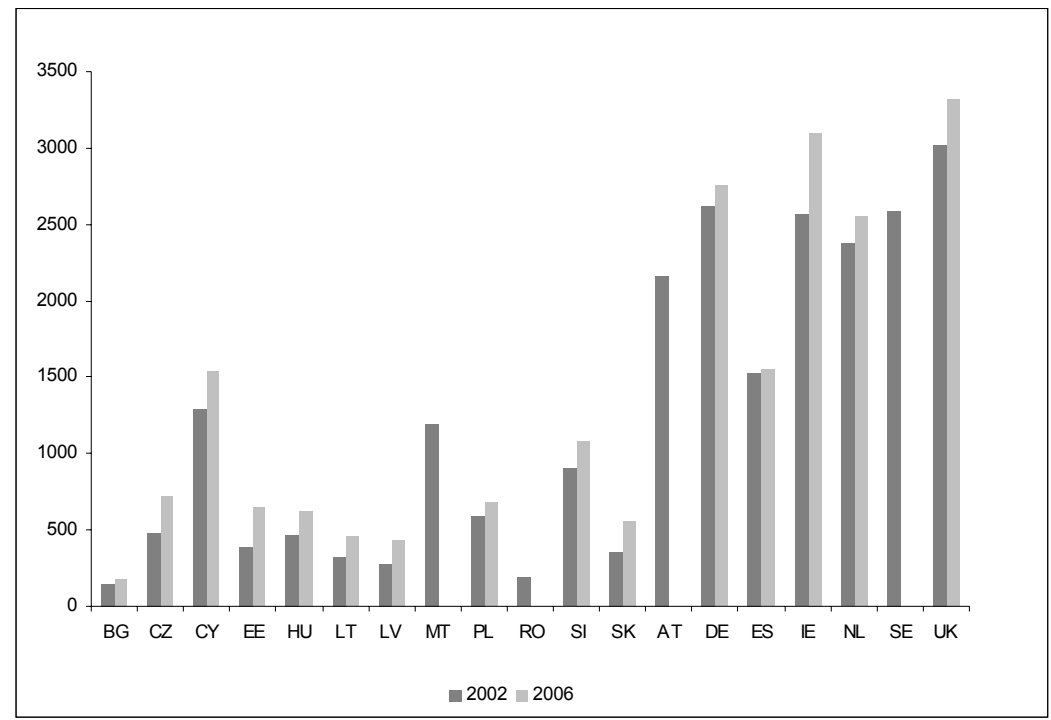

Source: Authors' calculations from the the Eurostat online database for Labour Market / Earnings / Structure of Earnings Survey 2002 (and 2006) / Monthly Earnings available at: http://epp.eurostat.ec.europa.eu/portal/page?_pageid=1996,45323734\&_dad=portal\&_schem $a=P O R T A L \& s c r e e n=w e l c o m e r e f \& o p e n=/ l a b o u r / e a r n / e a r n \_s e s / e a r n \_s e s \_m o \& l a n g u a g e=e n \&$ product=EU_MASTER_labour_market\&root=EU_MASTER_labour_market\&scrollto=171

\section{Figure 19}

Labor cost index: wages and salaries in the new member states

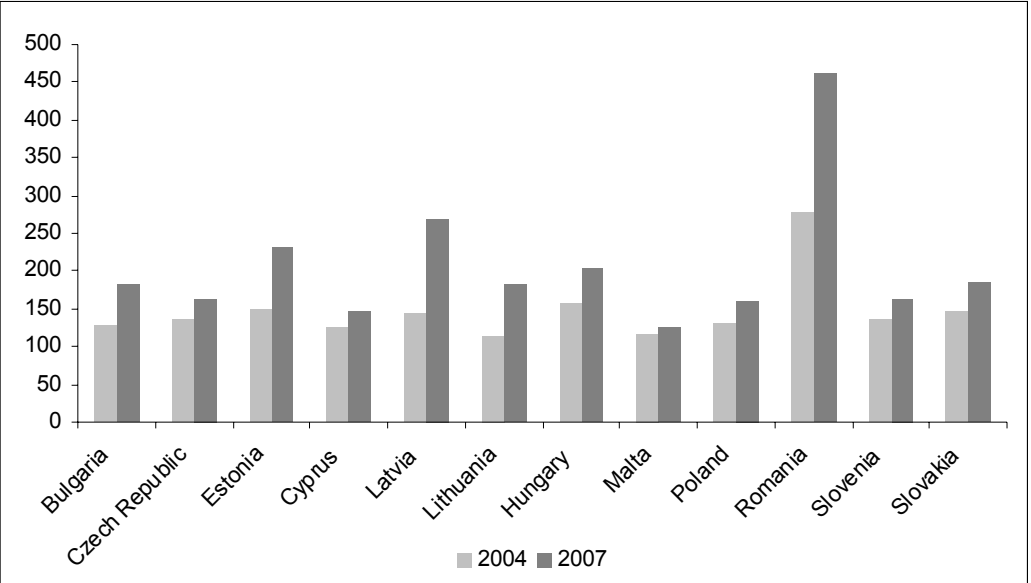

Source: Authors calculations based on data from the Eurostat online database for Population and Social Conditions / Labour Market / Labour Costs available at:

http://epp.eurostat.ec.europa.eu/portal/page?_pageid=1090,30070682,1090_30298591\&_da $d=$ portal\&_schema=PORTAL

Notes: Index $2000=100$. 
Another development has been increasing wages, and thus unit labor costs in the new member states, as suggested by Figures 18 and 19. However, wages in these countries are still several times lower than in the UK or Ireland (see Figure 18). The World Bank (2006) reports that the largest increases in the first quarter of 2006 were in the health sector in Lithuania and in agriculture in Poland and warns of potential inflationary pressures.

In general, one has to be careful, however, when correlating emigration with these new developments in the labor markets. According to Rutkowski (2007), the latest developments in the labor markets of new member countries are mainly driven by economic restructuring and only to a small extent by emigration. This is in line with conclusions in Kaczmarczyk and Okólski (2008) that fast growth rates and growing demand play an important role.

The relatively high level of education of these migrants together with the observed "downgrading" into less skilled occupations (due to incomplete transferability of migrants' skills) reported above may suggest a potential danger of "brain waste", when human capital depreciates during periods of low-skilled work in the host country. On the other hand, investing in language skills, expanding professional networks and learning other new skills abroad implies transferring these skills back home on returning. In addition, migrants may bring back home a migrant partner who is also likely to be well-educated, suggesting brain circulation in the long run (European Commission, 2008b). The World Bank (2006) argues that there was no incidence of massive "brain drain" from the new member states, although in some sectors (such as health care) the emigration of highly skilled specialists was relatively large. Indeed, around 4.3\% of Polish physicians in 2006 were interested in working abroad and had acquired the required certifications, which suggests a potential non-negligible brain drain from this sector (Frelak and Kazmierkiewicz, 2007). Overall, although the proportion of the highly educated emigrants from the new member states is above that of the stayers, especially for the EU8 emigrants (European Commission, 2008b; Brücker and Damelang, 2009; Brücker et al., 2009), the significant drain of skilled people is not observed (Brücker et al., 2009). At the same time, there is a tendency of increasing enrolment rates for tertiary education in the new EU member countries, which may compensate for the outflow of skilled labor (European Commission, 2008b; Brücker et al., 2009).

Finally, migrant remittances is another important issue when analyzing the consequences of emigration. As shown in Figure 20, remittances constitute a significant part of the GDP in Bulgaria and Romania, and they are also nonnegligible in the Baltic states. Their share increased in the majority of countries between 2003 and 2006. The remittances are mostly seasonal in nature in Poland and the Baltic states, which suggests a temporary seasonal pattern of migration from these countries (Kaczmarczyk and Okólski, 2008). Remittances are largely 
used for household consumption and the purchase of durable goods, but there has been a recent tendency to invest in human capital, particularly tertiary education (World Bank, 2006; Kaczmarczyk and Okólski, 2008).

Figure 20

Workers' remittances and compensation of employees, received

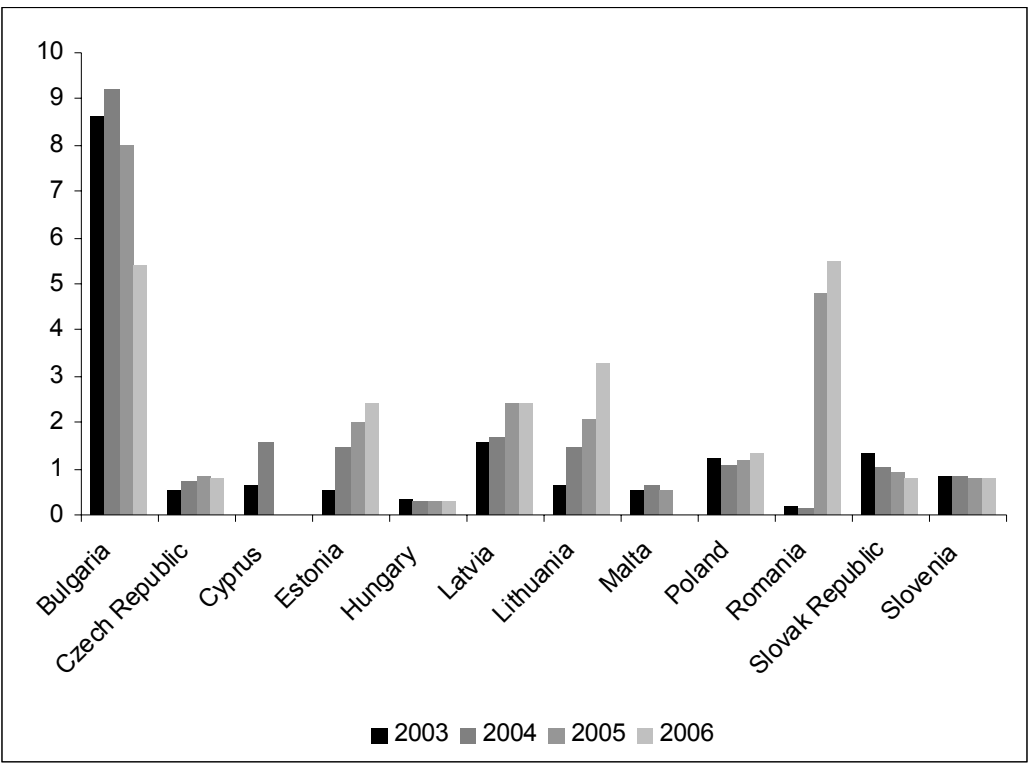

Source: World Bank World Development Indicators CD-Rom 2007 (for 2003-2005) and World Bank (2008)

Notes: In \% of GDP.

The impact of these remittances on the economic development so far is difficult to document, but they may play a positive role in the economic development of the new member states inasmuch as they support aggregate demand and investments in education and business activities. Another issue that deserves further investigation is how these remittances affect the decisions of "those who stay behind," including their labor supply and educational decisions. In addition, the consequences of all these effects on public budgets in the source countries are still to be fully studied. Overall, the World Bank (2006, p.1) concludes that although emigration from the new member states "...has led to skills shortages and bottlenecks in several sectors in the main sending countries and increased wage pressures, sending countries are benefiting from increased remittances from workers abroad who may also return with additional human capital." 


\section{$5 \quad$ The Current Economic Crisis}

With the downswing of European economies in early 2008, some deterioration of labor market variables have recently been observed in the destination countries (Figures 9-14). However, with the numbers of immigrants from the EU8 and EU2 declining and the rise of the global crisis, this can be hardly attributed to immigration. Similarly, the crisis is also affecting the new member states and potentially will cause a slowdown there too in vacancies and employment growth (see also Figure 17) as well as an increase in unemployment.

Obviously with the crisis, the "natural experiment" of politically determined enlargement and the opening up of some labor markets is coming to an end, or better said, moving to a different stage in the analysis. This is unfortunate, since the study of the outflow of EU8 and EU2 emigrants caused by enlargement, their size, performance and effects on the natives cannot be completed. Nevertheless, more information about this regime will be available with the release of micro data until 2008, since we currently often do not even have the 2007 data waves. With the release of the 2009 micro data at the latest, we will have to focus on a new research question, namely, the issue how under free mobility and an economic downturn migration will perform.

It is known that labor migrants are very responsive to economic cycles, especially if there are no mobility restrictions for returning home and re-returning to the host country. EU8 and EU2 immigrants in the EU15 countries do not face any long-term mobility constraints. To the contrary, mobility barriers are known to decline in the EU over the next years because some currently existing restrictions have to be removed. Also many migrants, especially among Poles were evaluated to be temporary movers. At times of high and rising unemployment, the general public, policy makers and companies become more concerned about the potential adverse effects of immigration on the job opportunities of natives. Consequently, rightly or wrongly, the social pressure on migrants to leave rises. Since social networks are very important for migrant job searches, an increase in unemployment will reduce the availability of valuable information, and hence employment chances of ethnic networks. Migrants are further over-educated while working in lower-paid jobs in the host country; if they become unemployed, they may prefer to return to more skilled occupations back home. This all suggests that many foreign workers will now, or with a further worsening of the crisis, move home.

This view has to be qualified. Unlike in normal business cycles, the current downturn is not asymmetric across economies but occurs parallel. This implies that migrants face a deepening of the crisis in both the host and home countries suggesting that it is less reasonable to return home. Even more, the relative situation in the old EU15 countries may still be better than the one in the new EU members. The crisis also affects the host economies differently. For instance, 
Germany is hit in the export-oriented investment goods industries with their many skilled workers; whereas Ireland and the United Kingdom suffer from a more global economic downturn. High-skilled immigrants, who are also typically young, single and with no other strong family ties in the host country, are more likely to return home than low-skilled immigrants who cannot expect to find a job back home. Moreover, such factors like established networks, language or the worsening economic situation at home may further serve as push or pull factors for east-west European migration. Indeed, Blanchflower and Lawton (2009) argue that inflows to the UK, for example, could remain strong well into the future; although the weight of the source countries may change, for example, with less people coming from Poland and more from Hungary, the Baltic states, Romania or Bulgaria.

\section{Conclusions}

This paper summarizes what we hitherto know about migration in the EU after the 2004 and 2007 enlargements. The Eastern enlargement of the EU removed some of the institutional migration barriers and was thus an impetus to the migration potential in Europe. While the overall numbers of migrants from the new member states in the EU15 increased between 2003 and 2007, this increase was unevenly distributed across countries. The proportion of migrants from the new member states in the EU15 remains noticeably lower (and their inflows exhibit slower dynamics) than that of non-EU migrants (apart from Ireland). In general, there does not seem to be any simple link between the transitional arrangements and the postenlargement migration. The increase in immigration from the EU8 was largest in Ireland and the UK, while the proportion of EU2 citizens in Spain and Italy continued to increase in 2007. The main source countries are Poland and Romania among the EU2 and EU8 countries and the largest shares of emigrants relative to the country's population are in Romania, Bulgaria, Lithuania and Poland.

Have these primarily economic migrants affected the host labor markets? They certainly brought skilled hands and new knowledge with them, and thus contributed to the economic development in the host countries. There has been no sufficient evidence so far to conclude that they would crowd out native labor from employment or lower their wages. Even if crowding out happened in certain sectors or occupations, aggregate data suggest that natives affected found new jobs elsewhere. Nor is there any evidence that this new labor is more dependent on welfare than the natives. Note, however, that the impacts may be different when disaggregating by local labor markets, sectors or skill groups. 
Concerning the new member states, the drain of mainly young and skilled people could pose some additional demographic challenges on countries experiencing significant outflows of people. It appears, however, that the migration trajectory is of a temporary nature. To the extent that these people return with not only accumulated human capital and new skills, but also financial resources, the anticipated brain circulation may in fact help solve demographic and economic problems in their countries of origin. Even before returning, they channel some resources back home in the form of remittances; these finances are most significant in Romania and Bulgaria, but also in the Baltic states. Those effects seem to be limited so far, but it is too early and too little researched to reach a valid conclusion at this stage.

Several caveats on these findings need to be mentioned, however. First, the time span may be still too short for any impact to be measurable. Second, the impacts may be greater when disaggregating into local labor markets, skill and immigrant groups. Third, these effects are inherently difficult to measure, mainly because it is hard to track international flows of migrants, account for the endogeneity of the migration decisions, and control for the confounding variables, including the reactions of natives and stayers to migrant flows. Yet, the period covered characterized by steady economic development lends itself to the analysis of the impacts of migration on EU labor markets. The current economic crisis will severely limit our ability to trace these impacts, since many migrants will return home (and not be documented) and the labor market conditions will have changed too substantially.

While the ongoing economic crisis may change the momentum of several migration trajectories, free migration should in fact alleviate many consequences of the crisis. Labor migrants are typically very responsive to economic cycles, especially if there are no mobility restrictions when returning home and re-returning to the host country. EU migrants do not face any such mobility constraints in the long term. Furthermore, many immigrants from the new member states considered themselves temporary movers. This, among other arguments, suggests that many foreign workers will move home now or soon. However, if the economic crisis has hit the home country stronger than the host country, or if labor market conditions at home are especially poor for low-skilled workers, return migration might be delayed.

Based on this account of the post-enlargement migration flows, it appears that the key scientific and policy challenges from this process have to do with the following themes. First, we would like to have a better notion about the size of future migration flows. Will many more people decide to leave new member states for the old ones, or will the numbers stabilize at much lower figures than current? Our preliminary account suggests that after the initial increase, which possibly involved legalizations, the net numbers of migrants have started to decline. Second, the composition of migration flows is a key factor driving their effects. 
Third, the decisions of the post-enlargement migrants about the timing, duration and frequency of their stays abroad affect the characteristics of the effects they may impinge upon the host and source labor markets. For example, these decisions determine not only the size but also the composition of the stock of immigrants in the host labor markets at each time. Furthermore, immigrant intentions regarding their planned length of stay influence the behavior of economic actors, such as their own decisions to invest in human capital specific to the host economy, or the behavior of investors to invest in different technologies that use immigrant labor. Circular migration is also a vehicle of knowledge transfer and thus may affect technological advancement in both source and destination countries.

Fourth, it is yet to be evaluated how the transitory arrangements have affected the post-enlargement migration flows and their repercussions. It appears that these arrangements have diverted some migrants to those old member states which opened their labor markets early on. There is evidence that they have affected the composition of migration flows and their consequences. For example, in contrast to those countries which liberalized access to their labor markets, it seems that the barriers applied in Germany possibly discouraged the most skilled migrants and thus lowered the average quality of the migrant inflows. Those who came, disproportionately work as entrepreneurs - probably as a means to penetrate the German labor market despite the restrictions.

Finally, free mobility of people is a cornerstone of the European Union. How to ensure that it is upheld in all aspects, that it contributes to economic prosperity as well as the well-being of the individual and the society, and that it helps to alleviate economic and financial disturbances such as the ongoing economic crisis, is a major policy task for the present and future. 


\section{References}

Alvarez-Plata, P./H. Brücker/B. Siliverstovs (2003), Potential Migration from Central and Eastern Europe into the EU15 - An Update. Report for the European Commission, DG Employment and Social Affairs, German Institute for Economic Research (DIW Berlin).

Anderson, B./M. Ruhs/B. Rogaly/S. Spencer (2006), Fair Enough? Central and East European Migrants in Low-Wage Employment in the UK. Report published by the Joseph Rowntree Foundation, London.

Baas, T./H. Brücker/A. Hauptmann (2009), Labor Mobility in the Enlarged EU: Who Wins, Who Loses?, in: M. Kahanec/K. F. Zimmermann (eds.), EU Labor Markets After PostEnlargement Migration. Berlin et al., 47-70.

Barrett, A./D. Duffy (2007), Are Ireland's Immigrants Integrating into its Labour Market? IZA Discussion Paper No. 2838, Bonn.

Barrett, A./S. McGuinness/M. O'Brien (2008), The Immigrant Earnings Disadvantage across the Earnings and Skills Distributions: The Case of Immigrants from the EU's New Member States in Ireland. IZA Discussion Paper No. 3479, Bonn.

Becker, G. S. (1957), The Economics of Discrimination. Chicago.

Blanchflower, D. G./H. Lawton (2009), The Impact of the Recent Expansion of the EU on the UK Labour Market, in: M. Kahanec/K. F. Zimmermann (eds.), EU Labor Markets After Post-Enlargement Migration. Berlin et al., 181-215.

Blanchflower, D. G./C. Shadforth (2009), Fear, Unemployment and Migration, in: The Economic Journal 119 (535), F136-F182.

Blanchflower, D. G./J. Saleheen/C. Shadforth. (2007), The Impact of the Recent Migration from Eastern Europe on the UK Economy. IZA Discussion Paper No. 2615, Bonn.

Boeri, T./H. Brücker (2005), Migration, Co-ordination Failures and EU Enlargement, in: Economic Policy, 20 (44), 629-703.

Bonin, H./W. Eichhorst/C. Florman/M. O. Hansen/L. Skiöld/J. Stuhler/K. Tatsiramos/H. Thomasen/K. F. Zimmermann (2008), Geographic Mobility in the European Union: Optimising its Economic and Social Benefits. IZA Research Report No. 19, Bonn.

Bonin, H./B. Raffelhüschen/J. Walliser (2000), Can Immigration Alleviate the Demographic Burden?, in: FinanzArchiv 57 (1), 1-21.

Borjas, G. J. (1985), Assimilation, Changes in Cohort Quality, and the Earnings of Immigrants, in: Journal of Labour Economics 3 (4), 463-489.

Borjas, G. J. (1987), Self-Selection and the Earnings of Immigrants, in: American Economic Review 77 (4), 531-553.

Borjas, G. J. (1999), Immigration and Welfare Magnets, in: Journal of Labor Economics 17 (4), 607-637.

Brenke, K./K. F. Zimmermann (2007), Zuwanderung aus Mittel- und Osteuropa trotz Arbeitsmarktbarrieren deutlich gestiegen, in: DIW-Wochenbericht 44, 645-653.

Brenke, K./M. Yuksel/K. F. Zimmermann (2009), EU Enlargement under Continued Mobility Restrictions: Consequences for the German Labor Market, in: M. Kahanec/K. F. Zimmermann (eds.), EU Labor Markets After Post-Enlargement Migration. Berlin et al., 111-129.

Brücker, H./A. Damelang (2009), Labour Mobility within the EU in the Context of Enlargement and the Functioning of the Transitional Arrangements. Analysis of the Scale, Direction and Structure of Labour Mobility. Deliverable 2. IAB, Nürnberg. 
Brücker, H. et al. (2009), Labour Mobility within the EU in the Context of Enlargement and the Functioning of the Transitional Arrangements. Final Report (IAB, CMR, fRDB, GEP, WIFO, wiiw), Nürnberg.

Brücker, H./G. S. Epstein/B. McCormick/G. Saint-Paul/A. Venturini/K. F. Zimmermann (2002), Managing Migration in the European Welfare State, in: T. Boeri/G. Hanson/B. McCormick (eds.), Immigration Policy and the Welfare System. Oxford, 1-168.

Burda, M. C. (1995), Migration and the Option Value of Waiting, in: Economic and Social Review 27, 1-19.

Chiswick, B. R. (1980), An Analysis of the Economic Progress and Impact of Immigrants, Employment and Training Administration. U.S. Department of Labor. National Technical Information Service, Washington DC, PB80-200454.

Chiswick, B. R. (1998), The Economic Consequences of Immigration: Application to the United States and Japan, in: M. Weiner/T. Hanami (eds.), Temporary Workers or Future Citizens? Japanese and U.S. Migration Policies. New York, 177-208.

Chiswick, B. R. (1999), Are Immigrants Favorably Self-Selected?, in: American Economic Review 89 (2), 181-185.

Chiswick, C. U./B. R. Chiswick/G. Karras (1992), The Impact of Immigrants on the Macroeconomy. Carnegie-Rochester Conference Series on Public Policy, 37 (1), 279-316.

De Giorgi, G./M. Pellizzari (2006), Welfare Migration in Europe and the Cost of a Harmonised Social Assistance. IZA Discussion Paper No. 2094, Bonn.

D'Auria, F./K. Mc Morrow/K. Pichelmann (2008), Economic Impact of Migration Flows following the 2004 Enlargement Process: A Model Based Analysis, European Economy. Economic Papers No. 349, Brussels (European Commission).

Doyle, N. (2007), The Effects of Central European Labor Migration on Ireland, in: J. SmithBozek (ed.), Labor Mobility in the European Union: New Members, New Challenges. Washington DC (Center for European Policy Analysis), 35-59.

Doyle, N./G. Hughes/E. Wadensjö (2006), Freedom of Movement for Workers from Central and Eastern Europe - Experiences in Ireland and Sweden. Swedish Institute for European Policy Studies (SIEPS), Report No. 5, Stockholm.

Drinkwater, S./J. Eade/M. Garapich (2006), Poles Apart? EU Enlargement and the Labour Market Outcomes of Immigrants in the UK. IZA Discussion Paper No. 2410, Bonn.

European Commission (2006a), Report on the Functioning of Transitional Arrangements set out in the 2003 Accession Treaty (period 1 May 2004 - 30 April 2006). Communication from the Commission to the Council, the European Parliament, the European Economic and Social Committee and the Committee of the Regions. Brussels, 8 February 2006.

European Commission (2006b), Enlargement Two Years After: An Economic Evaluation, European Economy. Directorate-General for Economic and Financial Affairs, Occasional Paper No. 24. Brussels, 3 May 2006.

European Commission (2008a), The Impact of Free Movement of Workers in the Context of EU Enlargement, Report on the first phase (1 January 2007 - 31 December 2008) of the Transitional Arrangements set out in the 2005 Accession Treaty and as requested according to the Transitional Arrangements set out in the 2003 Accession Treaty. Communication from the Commission to the European Parliament, the Council, the European Economic and Social Committee and the Committee of the Regions. Brussels, 18 November 2008.

European Commission (2008b), Employment in Europe, Chapter 3: Geographical labour mobility in the context of EU enlargement. Directorate-General for Employment, Social Affairs and Equal Opportunities. Office for Official Publications of the European Communities. Luxembourg, October 2008. 
European Commission (2009), Five Years of an Enlarged EU - Economic Achievements and Challenges. European Economy, No. 1/2009.

Fouarge, D./P. Ester (2007a), Determinants of Migration Intentions in Europe. Exodus or Bounded Mobility? Institute for Labour Studies, Tilburg University, mimeo.

Fouarge, D./P. Ester (2007b), Factors Determining International and Regional Migration in Europe. European Foundation for the Improvement of Living and Working Conditions, Dublin.

Frelak, J./P. Kazmierkiewicz (2007), Labor Mobility: The Case of Poland, in: J. SmithBozek (ed.), Labor Mobility in the European Union: New Members, New Challenges. Washington DC (Center for European Policy Analysis), 60-79.

Gerdes, C./E. Wadensjö (2008), Immigrants from the New EU Member States and the Swedish Welfare State. Swedish Institute for European Policy Studies (SIEPS), Report No. 9, Stockholm.

Gilpin, N./M. Henty/S. Lemos/J. Portes/C. Bullen (2006), The Impact of Free Movement of Workers from Central and Eastern Europe on the UK Labour Market. Department of Work and Pensions, Working Paper No. 29, London.

Harris, J. R./M. P. Todaro (1970), Migration, Unemployment and Development: A TwoSector Analysis, in: American Economic Review 60 (1), 126-142.

Hatton, T. J./J. G. Williamson (2005), What Fundamentals Drive World Migration?, in: G. J. Borjas/J. Crisp (eds.), Poverty, International Migration and Asylum. Palgrave Macmillan, 15-38, Basingstoke.

Home Office (2009), Accession Monitoring Report May 2004 - December 2008, UK Border Agency, London.

Hughes, G. (2007), EU Enlargement and Labour Market Effects of Migration to Ireland from Southern, Central and Eastern Europe (Paper presented at Second IZA Migration Workshop: EU Enlargement and the Labour Markets, Bonn, 7-8 September 2007).

Iglicka, K. (2005), The Impact of the EU Enlargement on Migratory Movements in Poland. Center for International Relations, Report No. 12/05, Warsaw.

Kaczmarczyk, P./M. Okólski (2008), Economic Impacts of Migration on Poland and the Baltic States. Fafo-Paper 2008: 1, Oslo.

Kadziauskas, G. (2007), Lithuanian Migration: Causes, Impacts and Policy Guidelines, in: J. Smith-Bozek (ed.), Labor Mobility in the European Union: New Members, New Challenges. Washington DC (Center for European Policy Analysis), 80-100.

Kahanec, M./K. F. Zimmermann (2008), Migration, the Quality of the Labour Force and Economic Inequality. IZA Discussion Paper No. 3560, Bonn.

Kahanec, M./K. F. Zimmermann (2009), International Migration, Ethnicity and Economic Inequality, in: W. Salverda/B. Nolan/T. M. Smeeding (eds.), The Oxford Handbook of Economic Inequality. Oxford, 455-490.

Lemos, S./J. Portes (2008), The Impact of Migration from the New European Union Member States on Native Workers. Department for Work and Pensions, Working Paper No. 52, Leeds.

Massey, D. S. (1990), Social Structure, Household Strategies, and the Cumulative Causation of Migration, in: Population Index 56 (1), 3-26.

Mincer, J. (1978), Family Migration Decisions, in: Journal of Political Economy 86 (5), 749-773.

Pollard, N./M. Latorre/D. Sriskandarajah (2008), Floodgates or Turnstiles? Post-EU Enlargement Migration Flows to (and from) the UK. Institute for Public Policy Research, London.

Rutkowski, J. (2007), Labor Markets in EU8+2: From the Shortage of Jobs to the Shortage of Skilled Workers. World Bank EU8+2 Regular Economic Report Special Topic, Washington DC. 
Sjaastad, L. A. (1962), The Costs and Returns of Human Migration, in: Journal of Political Economy 70(5), 80-93.

Stark, O. (1991), The Migration of Labor. Cambridge.

Wadensjö, E. (2007), Migration to Sweden from the New EU Member States. IZA Discussion Paper No. 3190, Bonn.

World Bank (2006), International Migration, Remittances and the Brain Drain. Washington DC.

World Bank (2008), World Development Indicators 2008. Washington DC.

Zaiceva, A./K. F. Zimmermann (2008), Scale, Diversity, and Determinants of Labour Migration in Europe, in: Oxford Review of Economic Policy 24 (3), 427-451. 